\title{
Waste Isolation Pilot Plant Environmental Monitoring Plan
}

\author{
U.S. Department of Energy
}

Revision 3

March 2008

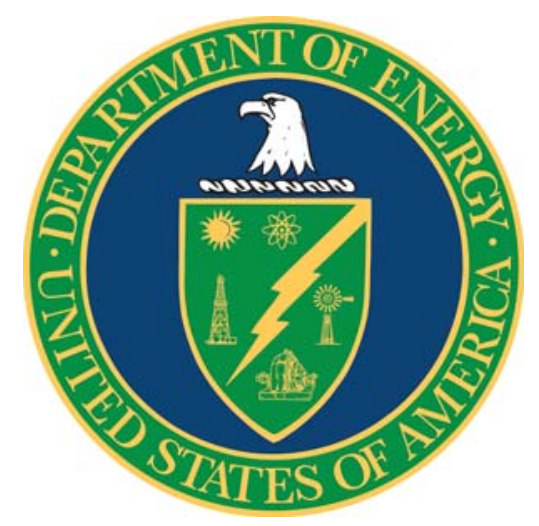


This document has been submitted as required to:

Office of Scientific and Technical Information

P.O. Box 62

Oak Ridge, TN 37831

(865) 576-8401

Additional information about this document may be obtained by calling the WIPP Information Center at 1-800-336-9477. Copies may be obtained by contacting the National Technical Information Service, U.S. Department of Commerce, 5285 Port Royal Road, Springfield, VA 22101.

Processing and final preparation of this document was performed by Washington TRU Solutions LLC, the Waste Isolation Pilot Plant (WIPP) management and operating (M\&O) contractor under U.S. Department of Energy contract number DE-AC29-01AL66444. 


\section{PREFACE}

U.S. Department of Energy (DOE) Order 450.1, Environmental Protection Program, requires each DOE site to conduct environmental monitoring. Environmental monitoring at the Waste Isolation Pilot Plant (WIPP) is conducted in order to:

- Verify and support compliance with applicable federal, state, and local environmental laws, regulations, permits, and orders.

- $\quad$ Establish baselines and characterize trends in the physical, chemical, and biological condition of effluent and environmental media.

- Identify potential environmental problems and evaluate the need for remedial actions or measures to mitigate the problems.

- $\quad$ Detect, characterize, and report unplanned releases.

- Evaluate the effectiveness of effluent treatment and control, and pollution abatement programs.

- $\quad$ Determine compliance with commitments made in environmental impact statements, environmental assessments, safety analysis reports, or other official DOE documents.

This Environmental Monitoring Plan (EMP) explains the rationale and design criteria for the environmental monitoring program, extent and frequency of monitoring and measurements, procedures for laboratory analyses, quality assurance (QA) requirements, program implementation procedures, and direction for the preparation and disposition of reports. Changes to the environmental monitoring program may be necessary to allow the use of advanced technology and new data collection techniques. This EMP will document changes in the environmental monitoring program. Guidance for preparation of EMPs is contained in DOE/EH-0173T, Environmental Regulatory Guide for Radiological Effluent Monitoring and Environmental Surveillance. 


\section{Waste Isolation Pilot Plant Environmental Monitoring Plan

\section{TABLE OF CONTENTS}

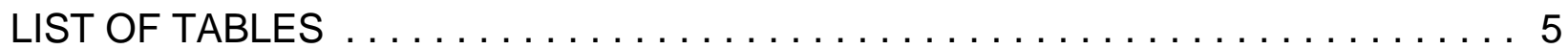

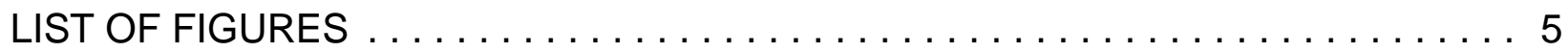

ABBREVIATIONSIACRONYMS $\ldots \ldots \ldots \ldots \ldots \ldots \ldots \ldots \ldots \ldots \ldots \ldots \ldots \ldots \ldots \ldots$

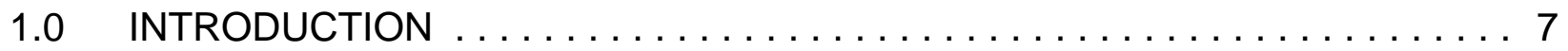

2.0 PROJECT DESCRIPTION $\ldots \ldots \ldots \ldots \ldots \ldots \ldots \ldots \ldots \ldots \ldots$

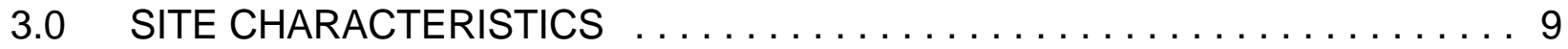

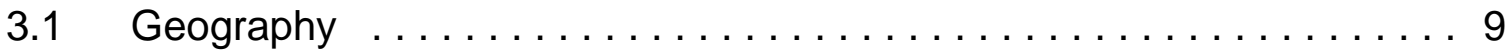

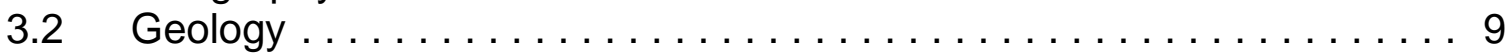

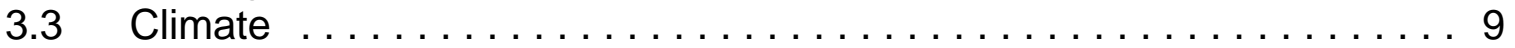

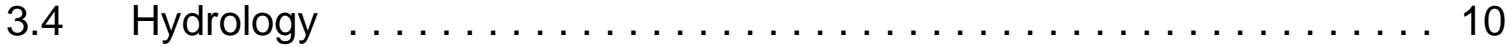

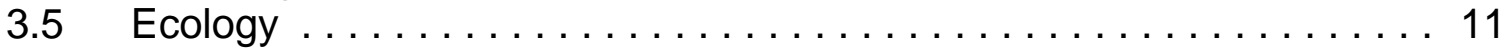

4.0 DOSE CALCULATIONS $\ldots \ldots \ldots \ldots \ldots \ldots \ldots \ldots \ldots \ldots \ldots \ldots \ldots \ldots$

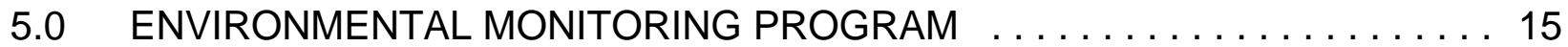

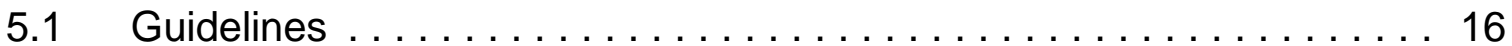

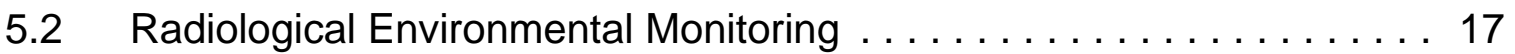

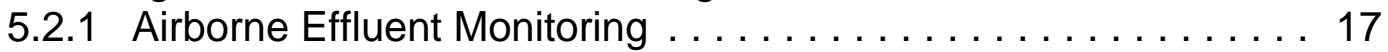

5.2 .2 Airborne Particulate Sampling ............... 18

5.2.3 Sewage Treatment System and H-19 Evaporation Pond

Sampling ........................ 18

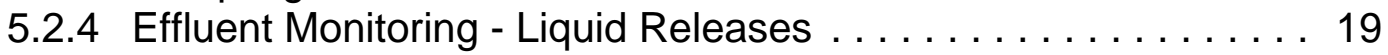

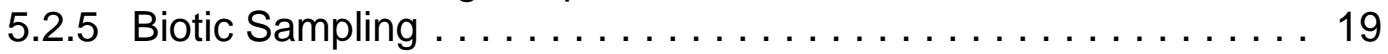

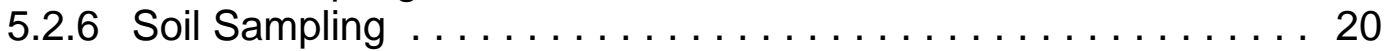

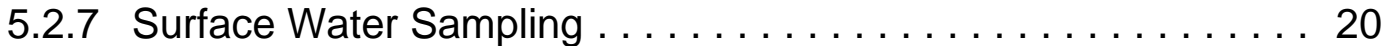

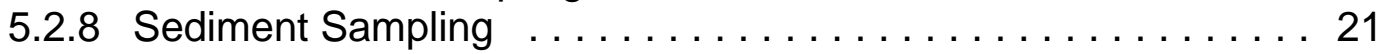

5.2 .9 Groundwater Sampling . . . . . . . . . . . . . . 21

$5.3 \quad$ Nonradiological Environmental Monitoring $\ldots \ldots \ldots \ldots \ldots \ldots \ldots 22$

5.3 .1 Meteorological Monitoring ................... 23

5.3.2 Volatile Organic Compound Monitoring ............ 23

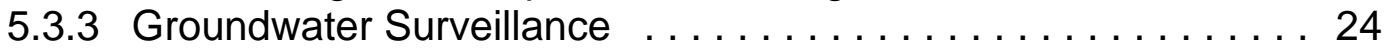

5.3.4 WIPP Shallow Subsurface Water Monitoring . . . . . . . . 24

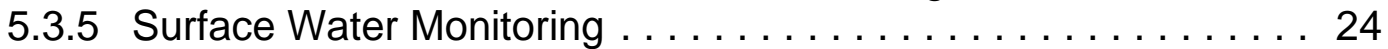

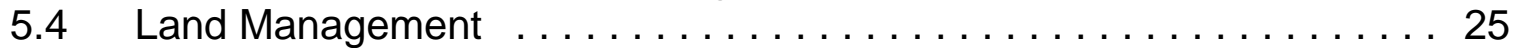

5.5 Oil and Gas Surveillance . . . . . . . . . . . . . . . . . . . 25

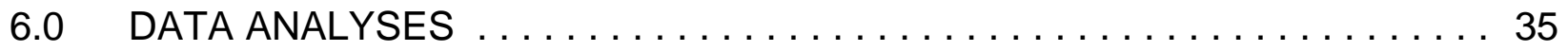

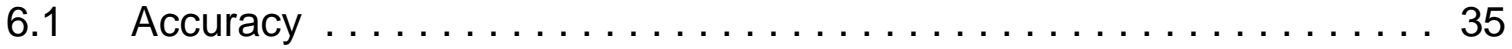

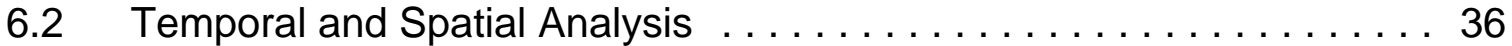

6.3 Distributions and Descriptive Statistics $\ldots \ldots \ldots \ldots \ldots \ldots \ldots$ 
$6.4 \quad$ Data Anomalies $\ldots \ldots \ldots \ldots \ldots \ldots \ldots \ldots \ldots \ldots \ldots \ldots \ldots \ldots \ldots \ldots$

6.5 Data Comparisons . . . . . . . . . . . . . . . . . . . 37

6.6 Laboratory Procedures $\ldots \ldots \ldots \ldots \ldots \ldots \ldots \ldots \ldots \ldots \ldots \ldots \ldots \ldots$

6.7 Sample Handling $\ldots \ldots \ldots \ldots \ldots \ldots \ldots \ldots \ldots \ldots \ldots \ldots \ldots$

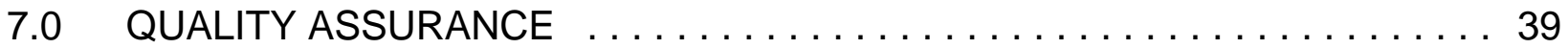

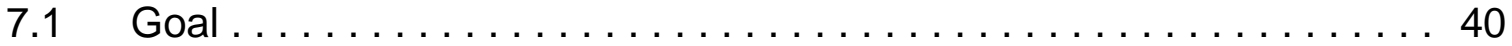

7.2 Program Elements/Criteria $\ldots \ldots \ldots \ldots \ldots \ldots \ldots \ldots \ldots \ldots \ldots 40$

7.2 .1 Program ....................... 40

7.2.2 Personnel Training and Qualification . . . . . . . . . . 41

7.2 .3 Quality Improvement $\ldots \ldots \ldots \ldots \ldots \ldots \ldots \ldots \ldots \ldots \ldots \ldots \ldots$

7.2 .4 Documents and Records $\ldots \ldots \ldots \ldots \ldots \ldots \ldots \ldots \ldots \ldots 4$

7.2 .5 Work Processes . . . . . . . . . . . . . . . . . 42

7.2 .6 Design $\ldots \ldots \ldots \ldots \ldots \ldots \ldots \ldots \ldots \ldots \ldots \ldots \ldots \ldots 44$

7.2 .7 Procurement . . . . . . . . . . . . . . . . . . 44

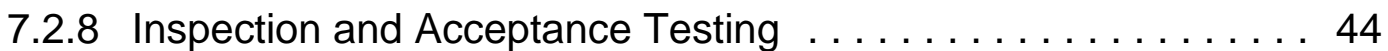

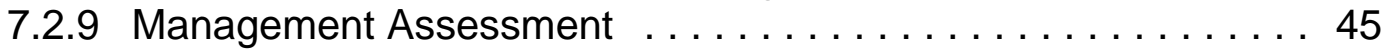

7.2 .10 Independent Assessment . . . . . . . . . . . . . . . 45

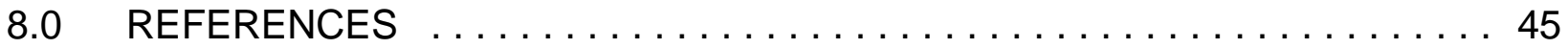

\section{LIST OF TABLES}

Table 5-1 - Environmental Monitoring Sampling $\ldots \ldots \ldots \ldots \ldots \ldots \ldots \ldots \ldots$

Table 5-2 - MP Analytical Array . . . . . . . . . . . . . . . . . . . 27

\section{LIST OF FIGURES}

Figure $3-1$ - Location of the WIPP Site $\ldots \ldots \ldots \ldots \ldots \ldots \ldots \ldots \ldots \ldots \ldots \ldots$

Figure $3-2$ - Plat of the WIPP Site $\ldots \ldots \ldots \ldots \ldots \ldots \ldots \ldots \ldots \ldots \ldots \ldots \ldots \ldots \ldots \ldots \ldots \ldots$

Figure 3-3 - Generalized Stratigraphy of the WIPP Site . . . . . . . . . . . . . 14

Figure 5-1 - Air Sampling Sites . . . . . . . . . . . . . . . . . . 28

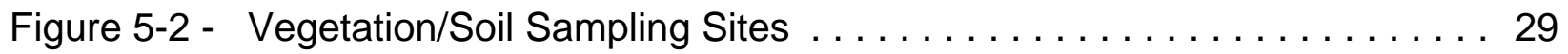

Figure $5-3$ - Surface Water Sampling Sites $\ldots \ldots \ldots \ldots \ldots \ldots \ldots \ldots \ldots \ldots \ldots$

Figure 5-4 - Groundwater Level Surveillance Wells . . . . . . . . . . . . . . 31

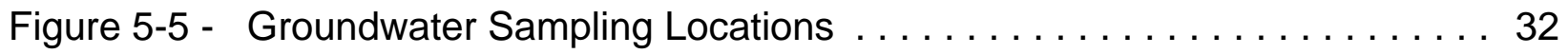

Figure $5-6$ - Sediment Sampling Sites $\ldots \ldots \ldots \ldots \ldots \ldots \ldots \ldots \ldots \ldots \ldots \ldots \ldots \ldots \ldots \ldots$

Figure 5-7 - Locations of SSW Wells (Piezometers PZ-1 through 12;

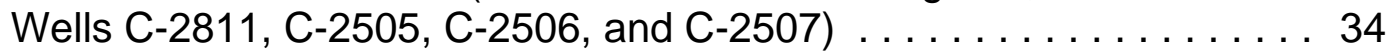




\section{ABBREVIATIONSIACRONYMS}

\begin{tabular}{|c|c|}
\hline ANSI & American National Standards Institute \\
\hline ASER & Annual Site Environmental Report \\
\hline ASME & American Society of Mechanical Engineers \\
\hline $\begin{array}{l}\text { CFR } \\
\mathrm{CH}\end{array}$ & Code of Federal Regulations \\
\hline DOE & U.S. Department of Energy \\
\hline EMP & Environmental Monitoring Plan \\
\hline EPA & U.S. Environmental Protection Agency \\
\hline FEIS & Final Environmental Impact Statement \\
\hline HEPA & high-efficiency particulate air (filter) \\
\hline HWFP & hazardous waste facility permit \\
\hline Lo-Vol & low-volume \\
\hline LUR & land use request \\
\hline NQA & Nuclear Quality Assurance \\
\hline$P Z$ & piezometer \\
\hline QA & quality assurance \\
\hline $\begin{array}{l}\text { QAPD } \\
\text { QC }\end{array}$ & $\begin{array}{l}\text { Quality Assurance Program Description } \\
\text { quality control }\end{array}$ \\
\hline $\begin{array}{l}\text { RCRA } \\
\text { RH }\end{array}$ & $\begin{array}{l}\text { Resource Conservation and Recovery Act } \\
\text { remote-handled }\end{array}$ \\
\hline SSW & shallow subsurface water \\
\hline TDS & total dissolved solids \\
\hline TKN & total Kjeldahl nitrogen \\
\hline TRU & transuranic \\
\hline VOC & volatile organic compound \\
\hline WHB & Waste Handling Building \\
\hline WIPP & Waste Isolation Pilot Plant \\
\hline WTS & Washington TRU Solutions LLC \\
\hline WQSP & water quality sampling program \\
\hline
\end{tabular}




\section{Waste Isolation Pilot Plant Environmental Monitoring Plan \\ DOE/WIPP-99-2194, Rev. 3}

\section{$1.0 \quad$ INTRODUCTION}

U.S. Department of Energy (DOE) Order 450.1, Environmental Protection Program, requires each DOE site to conduct environmental monitoring. Environmental monitoring at WIPP is conducted to:

- $\quad$ Verify and support compliance with applicable federal, state, and local environmental laws, regulations, permits, and orders.

- $\quad$ Establish baselines and characterize trends in the physical, chemical, and biological condition of effluent and environmental media.

- $\quad$ Identify potential environmental problems and evaluate the need for remedial actions or measures to mitigate the problem.

- $\quad$ Detect, characterize, and report unplanned releases.

- $\quad$ Evaluate the effectiveness of effluent treatment and control and pollution abatement programs.

- $\quad$ Determine compliance with commitments made in environmental impact statements, environmental assessments, documented safety analyses, or other official DOE documents.

This Environmental Monitoring Plan (EMP) explains the rationale and design criteria for the Environmental Monitoring Program, extent and frequency of monitoring and measurements, procedures for laboratory analyses, QA requirements, program implementation procedures, and direction for the preparation and disposition of reports. This EMP pertains to WIPP effluent, environmental monitoring, and land management programs during the facility's operational life, and also discusses the WIPP quality assurance/quality control (QA/QC) program as it relates to environmental monitoring.

This document is prepared for WIPP in accordance with the guidance contained in applicable sections of Environmental Regulatory Guide for Radiological Effluent Monitoring and Environmental Surveillance (DOE/EH-0173T; DOE, 1991).

This EMP provides a description of other environmental conditions at WIPP, including:

- $\quad$ A description of the WIPP Project and its mission.

- $\quad$ A description of the local environment.

- $\quad$ An overview of the methodology used to assess radiological consequences to the public. 


\section{Waste Isolation Pilot Plant Environmental Monitoring Plan DOE/WIPP-99-2194, Rev. 3}

Environmental activities at the WIPP Project generally fall into four categories:

(1) collecting environmental samples in various matrices and analyze them for specific parameters; (2) preparing and publishing documents showing compliance with federal, state, and local regulations; (3) evaluating whether WIPP activities cause adverse environmental impacts; and (4) taking corrective action when an adverse impact on the environment is identified due to any radiological or nonradiological source.

A number of provisions designed to mitigate potential environmental impacts appear, as applicable, in statements of work issued to contractors involved in the operation of the WIPP facility. These provisions are listed below:

- $\quad$ Protection of environmental resources, including avoidance of unnecessary damage to vegetation, wildlife, and soil by controlling traffic, preventing erosion, minimizing disturbance zones, and cleaning up spills

- $\quad$ Protection of air resources, including the control of hydrocarbon emissions by using proper fuels, the suppression of dust by spraying with water, and the monitoring and control of noise

- $\quad$ Protection of water resources, including the use of retention ponds such as the sewage treatment system for controlling suspended materials, solutes, and other pollutants

- $\quad$ Preservation and recovery of historical, archaeological, and cultural resources, including the delay of construction activities as necessary to investigate and mitigate impacts to historical or archaeological resources

- $\quad$ Post-construction reclamation, including the removal of temporary construction facilities, access roads, stockpiles, and work areas, as well as the restoration of all damaged landscape features outside the limits of approved work areas

WIPP must also comply with specified permitting and approval requirements of several federal and state regulatory agencies.

\subsection{PROJECT DESCRIPTION}

The primary purpose of WIPP is to dispose of defense-generated transuranic (TRU) waste, some of which is mixed TRU waste. Mixed TRU wastes are those containing both radioactive and hazardous constituents. TRU waste is radioactive waste that, without regard to source or form, is contaminated with alpha-emitting TRU radionuclides having atomic numbers larger than 92 and half-lives longer than 20 years in concentrations greater than 100 nanocuries per gram of waste.

Contact-handled $(\mathrm{CH})$ and remote-handled $(\mathrm{RH})$ TRU waste is being received and disposed of at the WIPP facility. $\mathrm{CH}$ waste consists of TRU waste that has a surface dose rate of $\mathbf{2 0 0}$ millirem per hour or less and therefore can be handled without additional shielding to protect personnel. $\mathrm{RH}$ waste is TRU waste that, due to higher 


\section{Waste Isolation Pilot Plant Environmental Monitoring Plan DOE/WIPP-99-2194, Rev. 3}

levels of penetrating radiation, must be shielded and/or handled remotely. Waste is classified as RH when the surface dose rate is 200 millirem per hour or greater.

$\mathrm{CH}$ and $\mathrm{RH}$ wastes are emplaced in rooms that have been excavated from the Salado Formation, a thick sequence of salt beds. The disposal horizon is located at a depth of 655 meters (2,150 feet). When a disposal room is deemed full, ventilation barriers are erected. When all of the rooms of a panel are full, the panel is removed from active ventilation.

When WIPP is decommissioned, specially designed shaft seals and closure systems will be placed in the excavated shafts and in the drifts. Geologic pressures and the plasticity of the salt will result in the excavation's gradual closure due to creep. This closure will encapsulate and isolate waste within the Salado Formation.

\subsection{SITE CHARACTERISTICS}

\subsection{Geography}

WIPP is located in Eddy County in southeastern New Mexico (Figure 3-1) within the Pecos Valley section of the southern Great Plains physiographic province (Powers et al., 1978). The site is $42 \mathrm{~km}$ (26 miles) east of Carlsbad in an area known as Los Medaños (the dunes). Los Medaños is a relatively flat, sparsely inhabited plateau with little surface water. The WIPP site (Figure 3-2) consists of 16 sections of federal land in Township 22 South, Range 31 East.

\subsection{Geology}

Los Medaños soils are sandy and well drained, with a well-developed caliche layer occurring below one meter. There are no integrated natural surface drainage features at the site. Scattered throughout the local area are numerous livestock watering ponds (tanks) and shallow playas which retain water sporadically. These playas are located approximately seven miles southwest of the site. Geologically, the site is located in the northern portion of the Delaware Basin, one of the western-most sedimentary basins known collectively as the Permian Basin. Figure 3-3 illustrates the local stratigraphy.

\subsection{Climate}

The climate of the region is semiarid, with generally mild temperatures, low precipitation and humidity, and a high evaporation rate. Winds are mostly from the southeast and moderate. In late winter and spring, there are strong west winds and dust storms.

Precipitation is light and unevenly distributed throughout the year, averaging 13 inches $(33 \mathrm{~cm})$ annually. Winter is the season of least precipitation, averaging less than 0.6 in. $(1.5 \mathrm{~cm})$ of rainfall per month. Snow averages about $5 \mathrm{in} .(13 \mathrm{~cm})$ per year at the site and seldom remains on the ground for more than a day at a time because of the typically above-freezing temperatures in the afternoon. Approximately half the annual precipitation comes from frequent thunderstorms in June through September. 


\section{Waste Isolation Pilot Plant Environmental Monitoring Plan DOE/WIPP-99-2194, Rev. 3}

Temperatures are moderate throughout the year, although seasonal changes are distinct. The mean annual temperature in southeastern New Mexico is $63^{\circ} \mathrm{F}\left(17.2^{\circ} \mathrm{C}\right)$. In the winter (December through February), night time lows average near $23^{\circ} \mathrm{F}\left(-5^{\circ} \mathrm{C}\right)$, and average maximum temperatures are in the 50s. In the summer (June through August), the daytime temperature exceeds $90^{\circ} \mathrm{F}\left(32.2^{\circ} \mathrm{C}\right)$ approximately 75 percent of the time (DOE, 2006).

\section{$3.4 \quad$ Hydrology}

The nearest large surface water body is located approximately 13 kilometers (eight miles) west-southwest of the WIPP site in Nash Draw. The Pecos River is located 22.4 kilometers (14 miles) southwest of the WIPP site.

Several water-bearing zones have been studied near WIPP. The most significant are the Culebra and Magenta members of the Rustler Formation, which consist primarily of fractured dolomite. These dolomite units produce brackish to saline water. Another saline water-bearing zone identified is the Rustler-Salado contact, which contains very little water at the WIPP site. It was exposed during shaft construction and produced only a small amount of brine seepage. Other water-bearing zones that have been evaluated as part of site characterization include the Dewey Lake Formation and the overlying Triassic Dockum Group above the repository, and the Bell Canyon and Castile Formations below the repository.

The Dewey Lake Formation (Figure 3-3), which contains limited amounts of fresh water, is composed of alternating thin, even beds of siltstone and mudstone with lenticular interbeds of fine-grained sandstone. Exploratory drilling during site hydrogeologic evaluation did not identify a continuous zone of saturation within the Dewey Lake. The few Dewey Lake wells yielding water for domestic and stock purposes are believed to be completed in the thin, discontinuous lenticular sands where favorable groundwater recharge occurs (Mercer, 1983).

Shallow subsurface water (SSW) occurs beneath the WIPP site at a depth of less than 100 feet below ground surface at the contact between the lower Santa Rosa Formation and the upper Dewey Lake Formation. This SSW yields generally less than 1 gallon per minute in monitoring wells and piezometers (PZs) and contains high concentrations of total dissolved solids (TDS) and chlorides. The origin of this water is believed to be primarily from anthropogenic sources. The SSW occurs not only under the WIPP site surface facilities but also about a half mile south of the Waste Handling Shaft.

The SSW saturated zone occurs in the uppermost Permo-Triassic Dewey Lake Formation and basal Triassic Santa Rosa Formation. Some wells in the PZ series produced dry cuttings in the uppermost Dewey Lake Formation, indicating that saturation was limited to the Santa Rosa/Dewey Lake formational contact. 


\section{$3.5 \quad$ Ecology}

The biota of Los Medaños represent a transition between the northern Chihuahuan Desert and the southern Great Plains. These sandy soils form stabilized coppice dunes interspersed with swales.

Shrubs and grasses are the most prominent components of the local flora. The area is composed of combined Havard shin oak (oak shinnery) dune and grassland aspects that include perennial grasses (e.g., gramma, dropseed, 3-awns) and shrubs (e.g., fourwing saltbush). These are typical grassland and shrub land species that dominate the flora of the area.

The area supports an abundant and diverse population of mammals. Black-tailed jackrabbits and desert cottontails are the most conspicuous. Other primary mammals include desert mule deer, desert dwelling rodents, and carnivores such as the coyote, gray fox, badger, and striped skunk.

A large variety of bird species are also found in the region. Densities vary according to food and habitat availability. Scaled quail, mourning dove, loggerhead shrike, pyrrhuloxia, and black-throated sparrows are examples of bird inhabitants. The Harris hawk, Chihuahuan raven, Swainson's hawk, Northern harrier, and American kestrel are also found at the site.

Numerous varieties of amphibians and reptiles also occupy the vicinity. Characteristic reptiles in the region include the western box turtle, side-blotched lizard, western whiptail, bullsnake, and prairie rattlesnake. Representative amphibians are the tiger salamander, green toad, and plain's spadefoot. A brief summary of the ecological baseline surveys appears in Appendix $\mathrm{H}$ of the Final Environmental Impact Statement, DOE/EIS-0026 (DOE, 1980). 


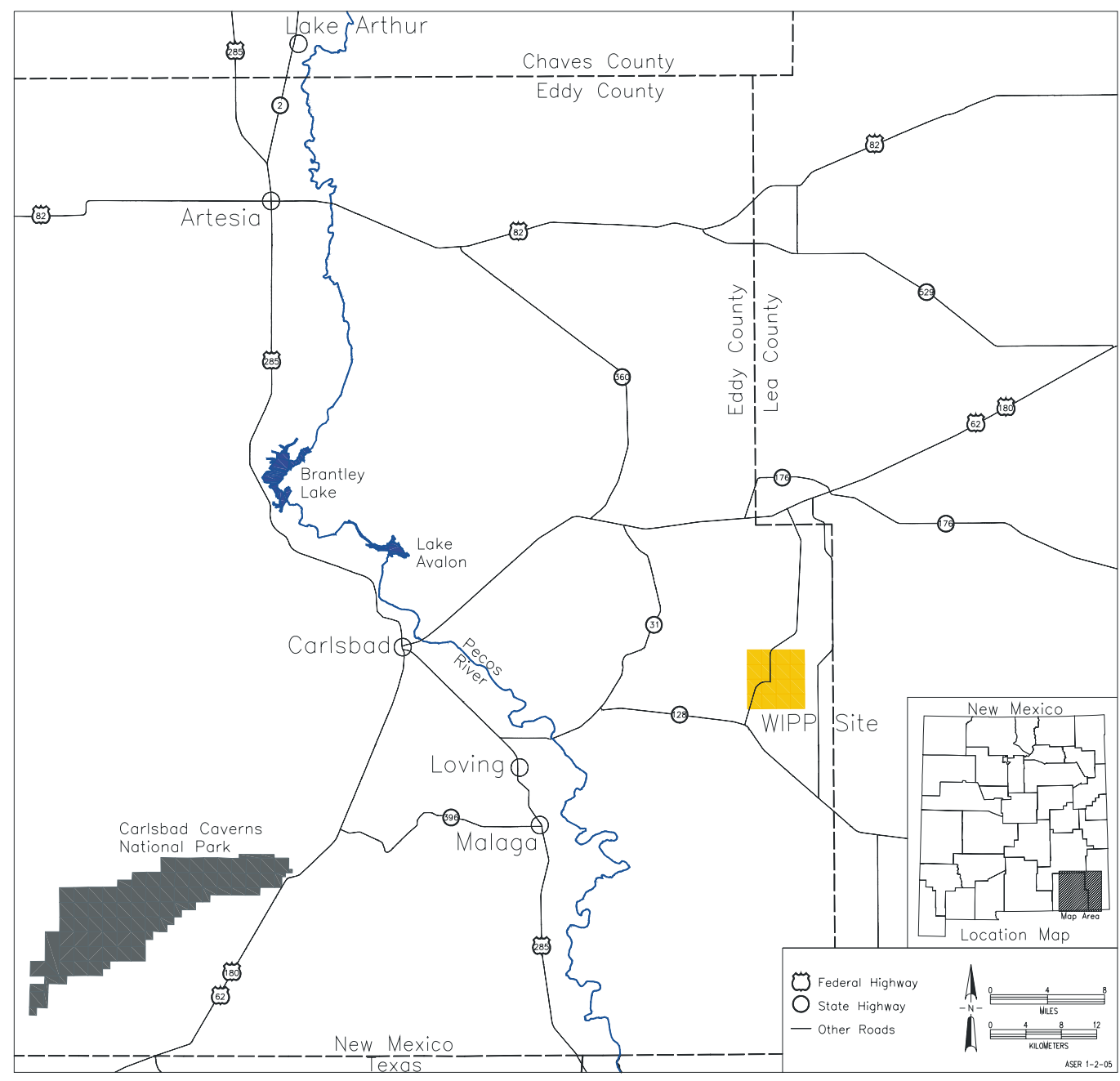

Figure 3-1 - Location of the WIPP Site 


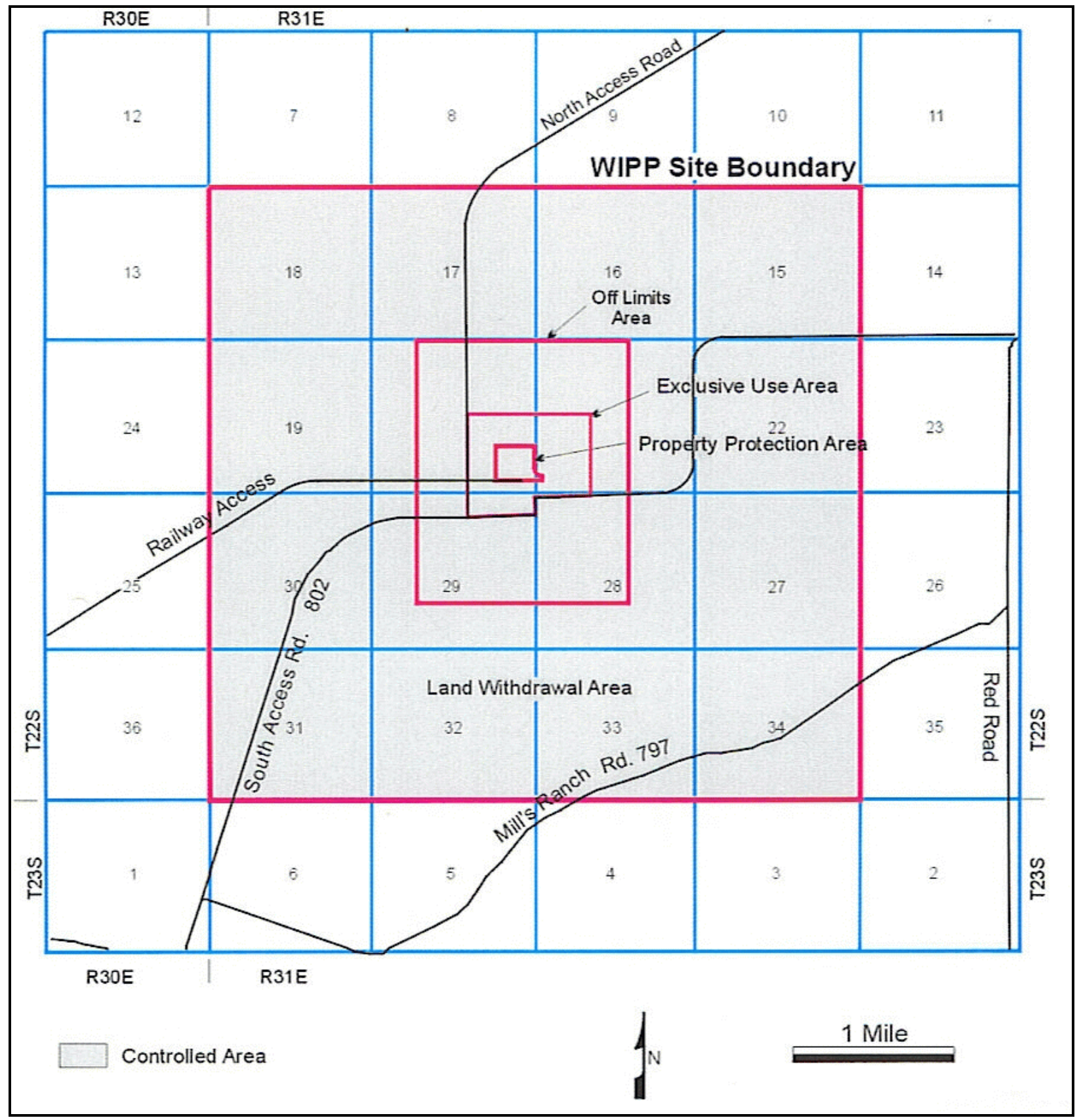

Figure 3-2 - Plat of the WIPP Site 


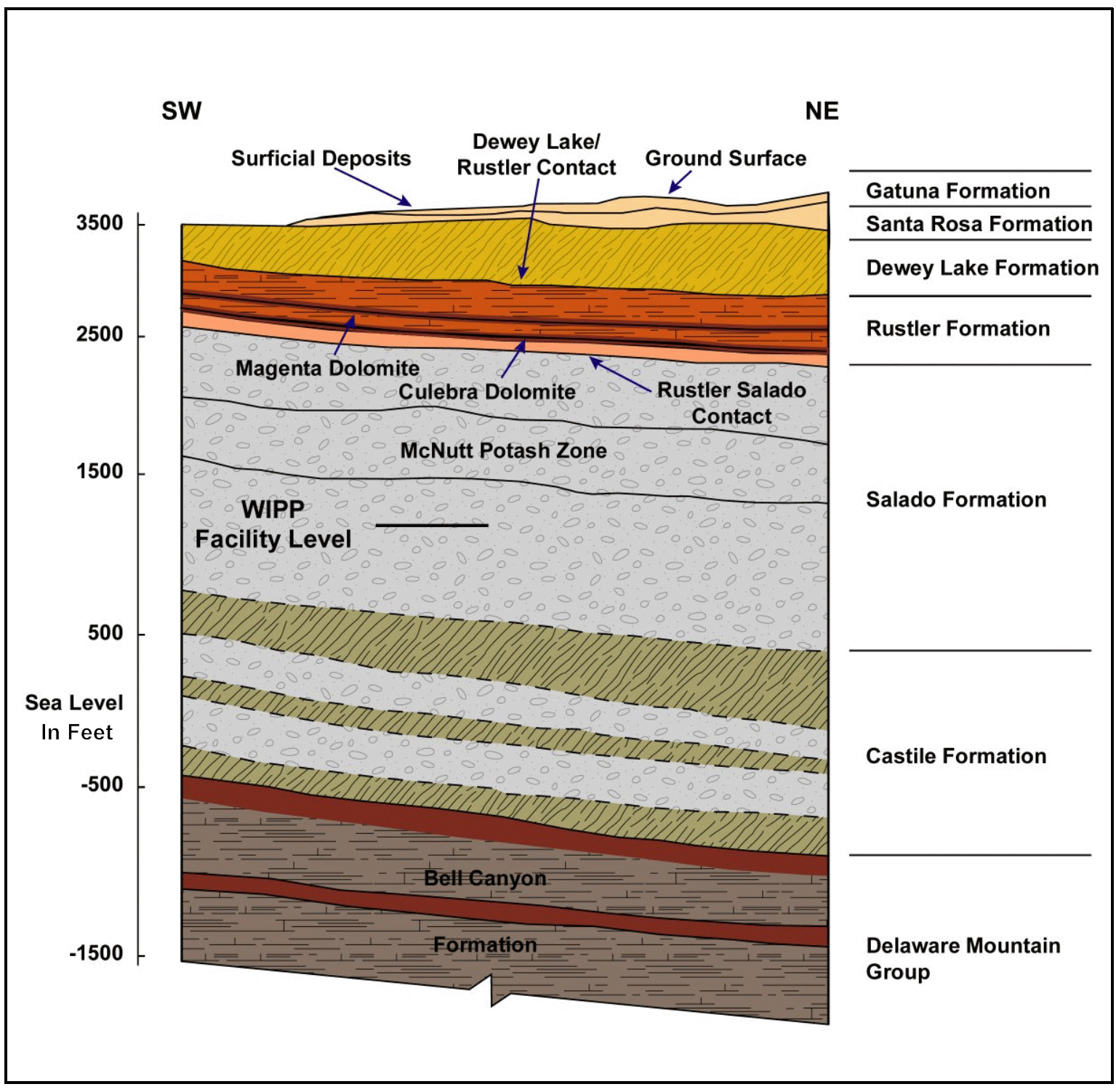

Figure 3-3 - Generalized Stratigraphy of the WIPP Site (Not to Scale)

\subsection{DOSE CALCULATIONS}

This section discusses dose calculations involving off-site dose assessment. Section 7.6.1 (Administrative Limits) of the Waste Isolation Pilot Plant Contact Handled (CH) Waste Documented Safety Analysis (DOE/WIPP 95-2065) (DOE, 2006a); and of the Waste Isolation Pilot Plant Remote Handled (RH) Waste Documented Safety Analysis (DOE/WIPP-06-3174) (DOE, 2006b) state: "Waste containers accepted for disposal at WIPP are expected to meet the Title 10 Code of Federal Regulations (CFR) Part 835 external contamination limits. WIPP normal operations do not involve any expected releases of airborne radioactive materials." 


\section{Waste Isolation Pilot Plant Environmental Monitoring Plan \\ DOE/WIPP-99-2194, Rev. 3}

WIPP is in compliance with the reporting requirements established by 40 CFR Part 61, Subpart H, "National Emissions Standards for Emissions of Radionuclides Other Than Radon From Department of Energy Facilities," and a memorandum of understanding dated May 16, 1995, between the U.S. Environmental Protection Agency (EPA) and the DOE regarding the provisions of the National Emission Standards for Hazardous Air Pollutants for radionuclides.

Emission monitoring and compliance procedures for DOE facilities (40 CFR §61.93[a]) require the use of CAP88-PC (Clean Air Act Assessment Package-1988) or AIRDOS-PC computer models, or other approved procedures, to calculate effective dose equivalents to members of the public. Calculations made using the CAP88-PC indicate that the effective dose equivalent to the maximally exposed individual resulting from normal operations conducted at the WIPP facility is well below the 10 millirem per year limit. This meets the requirements of 40 CFR Part 61, Subpart $\mathrm{H}$, for periodic confirmatory sampling.

\subsection{ENVIRONMENTAL MONITORING PROGRAM}

Each facility is required to ensure the early identification of, and appropriate response to, potential adverse environmental impacts associated with DOE operations. This must include appropriate preoperational characterization and assessment, and effluent monitoring. The DOE has complied with this requirement by compiling preoperational radiological and nonradiological data to use as a baseline for evaluating operational monitoring results.

An analysis of the historical preoperational data is contained in the following documents:

- Waste Isolation Pilot Plant RCRA Background Groundwater Quality Baseline Report (DOE/WIPP 98-2285c; DOE, 1998)

- $\quad$ Addendum 1, Waste Isolation Pilot Plant RCRA Background Groundwater Quality Baseline Update Report (IT Corporation, 2000)

- $\quad$ Statistical Summary of the Radiological Baseline for the WIPP (DOE/WIPP 92-037; DOE, 1992a)

- $\quad$ Summary of the Salt Impact Studies at the WIPP, 1984 to 1990 (DOE/WIPP 92-038; DOE, 1992b)

- $\quad$ A Study of Disturbed Land Reclamation Techniques for the WIPP (DOE/WIPP 92-039; DOE, 1992c)

- $\quad$ Background Water Quality Characterization Report for the WIPP (DOE/WIPP 92-013; DOE, 1992d)

The environmental sampling programs used to establish the preoperational baseline were originally defined in Chapter 5 of the Operational Environmental Monitoring Plan 


\section{Waste Isolation Pilot Plant Environmental Monitoring Plan DOE/WIPP-99-2194, Rev. 3}

(DOE, 1989). The plan evolved into this WIPP EMP. This EMP describes the current environmental monitoring efforts at WIPP during the operational (disposal) phase. Environmental monitoring data are compiled and published in the ASER.

\subsection{Guidelines}

Presidential Executive Order 12088, Federal Compliance with Pollution Control Standards, further requires the heads of executive agencies to ensure that federal facilities and activities comply with applicable pollution control standards and to take actions necessary for the prevention, control, and abatement of environmental pollution.

It is the policy of the DOE to conduct effluent monitoring and environmental surveillance programs that are appropriate for determining adequate protection of the public and the environment during DOE operations and to ensure that operations comply with DOE and other applicable federal, state, and local radiation standards and requirements. It is the DOE objective that DOE operations properly and accurately measure radionuclides in effluent streams and in the ambient environmental media.

A Guide for Environmental Radiological Surveillance at DOE Installations (Corley et al., 1981) states that the factors that should be considered in determining the relative level of environmental surveillance required at a facility include the following:

- $\quad$ Potential hazard of the materials released, considering both expected quantities and relative radiotoxicities

- $\quad$ Extent to which facility operations are routine and unchanging

- $\quad$ Need for supplementing and complementing effluent monitoring

- $\quad$ Size and distribution of the exposed population

- $\quad$ Cost-effectiveness of increments to the environmental surveillance program

- $\quad$ Availability of measurement techniques that will provide sufficiently sensitive comparisons with applicable standard and background measurements

The above guidance and the risk analysis in the safety analyses for WIPP that operational dose estimates for WIPP are significantly below dose criteria. The WIPP EMP encompasses a comprehensive set of parameters that detect environmental impacts. Also, the EMP scope and intensity may be adjusted in response to changing facility processes, environmental parameters, and program results.

Parameters measured relate to environmental radiation analysis of air, surface water and groundwater; sediments, soils, and biota; the status of the local biological community; and groundwater quality measurements. Nonradiological portions of the program focus on the immediate area surrounding the site, whereas radiological surveillance generally covers a broader geographical area including nearby ranches, 


\section{Waste Isolation Pilot Plant Environmental Monitoring Plan DOE/WIPP-99-2194, Rev. 3}

villages, and cities. Environmental monitoring will continue at the site during project operations and through decommissioning and beyond.

The goal of the environmental monitoring program is to determine if the local ecosystem has been impacted during the predisposal and disposal phases of WIPP and, if so, to evaluate the severity, geographic extent, and environmental significance. Tables 5-1 and 5-2 summarize the EMP sampling media, frequency, analytical array, and number of sampling stations. Environmental and ecological sampling during operations will be adjusted, as appropriate, to fit the needs of the project.

The geographic scope of radiological sampling is based on projections of potential release pathways for the types of radionuclides in WIPP wastes. Also, the surrounding population centers are monitored, even though release scenarios involving radiation doses to residents of those population centers are improbable.

Sampling and related activities are conducted in accordance with the procedures and instructions described in WIPP procedures. Standard sampling practices and techniques are used (see Section 6.0, Data Analysis).

QA/QC has been established within the framework of WP 13-1, Washington TRU Solutions LLC Quality Assurance Program Description (QAPD), and is described in Section 7.0 of this EMP. When WIPP data are received, they are evaluated and presented in the ASER.

\subsection{Radiological Environmental Monitoring}

The operational environmental surveillance program will continue, with some modifications of the preoperational program and parameters monitored during the radiological baseline program and ecological monitoring program, during the disposal phase. Each sampling subprogram of the EMP is described below.

\subsubsection{Airborne Effluent Monitoring}

The WIPP facility has three emission points. Monitoring Stations A, B, and C have been established at these air emission points. Station A samples unfiltered exhaust air from the underground repository to the atmosphere. Station B samples HEPA-filtered exhaust air from the underground repository to the atmosphere when in Filtration Mode of operation. Station C samples HEPA-filtered exhaust air from the Waste Handling Building (WHB) to the atmosphere. The WIPP facility uses skid-mounted fixed air samplers at each monitoring station to collect representative samples of airborne particulates. Sample filters are collected at the Station A fixed air sampler on a daily basis. Station B filters are collected weekly and at the end of each underground effluent filtration event, and as needed. Station C fixed air sampler filters are collected weekly, and as needed. Filters from all three monitoring stations are typically analyzed for gross alpha and beta activity. The sample filters are then composited and submitted for isotopic analysis $\left({ }^{238} \mathrm{Pu},{ }^{239 / 240} \mathrm{Pu},{ }^{241} \mathrm{Am}\right.$, and $\left.{ }^{90} \mathrm{Sr}\right)$ either monthly or quarterly depending on the frequency of filter changes from each station. Generally, Station A samples are 


\section{Waste Isolation Pilot Plant Environmental Monitoring Plan DOE/WIPP-99-2194, Rev. 3}

composited monthly, and Station B and C samples are composited quarterly. The results are reported annually in the ASER.

\subsubsection{Airborne Particulate Sampling}

The atmospheric pathway has been established as the most credible exposure pathway to the public from WIPP. Therefore, airborne particulate sampling for alpha-emitting radionuclides is emphasized in the EMP. Air sampling results are used to trend environmental radiological levels and determine if there has been a deviation from established background radiological levels.

To determine the number of air sampling stations and their placement, demographic and meteorologic data for the site were examined to determine the distance to local population centers, their population, and the wind frequency distribution and weighing factors, which are scaled to equal the desired number of sampling locations. Locations were selected to avoid areas where large-particle (nonrespirable) fugitive dusts can dominate the sample.

Low-volume fixed air samplers (Lo-Vols) operate at an average of two cubic feet per minute $(0.056$ cubic meters/minute) with a maximum of $\pm 0.2 \mathrm{cfm}$ deviation. The sample inlet probes are positioned in accordance with siting criteria contained in regulations and standards in effect at the time. Also, in sites free from unusual micro meteorological or other conditions (e.g., proximity of large buildings, vehicular traffic) that could result in air concentration measurements that are artificially high or low, the inlets are configured to provide a minimum of 270 degree sample radius.

The current Lo-Vol sampling array (Figure 5-1) consists of seven sampling stations, the locations of which provide as much continuity as possible between baseline and operational data. Lo-Vol samplers are at Carlsbad, Smith Ranch, Mills Ranch, WIPP South, WIPP East, WIPP Far Field, and the Southeast Control sites. The Southeast Control site is located approximately 12 miles southeast of WIPP. This air sampling location is in the predominant upwind direction of WIPP. One sampler is moved every calendar quarter to a different sampling location as a quality control measure.

Airborne particulate sampling is performed in accordance with WP 02-EM1012, Airborne Particulate Sampling, and includes steps for exchanging Lo-Vol filters weekly, desiccation, weighing and transmittal to a laboratory for counting and determining gross alpha and beta activity on a gas flow proportional counter. Quarterly composites of filters from each location undergo specific radionuclides analysis in accordance with Table 5-2.

\subsubsection{Sewage Treatment System and H-19 Evaporation Pond Sampling}

The WIPP sewage treatment system and the H-19 Evaporation Pond both have radiological and a nonradiological components. Both are presented here and in Table 5-2. The WIPP sewage treatment system consists of two parallel trains consisting of one settling pond and one polishing pond. Both polishing ponds discharge 


\section{Waste Isolation Pilot Plant Environmental Monitoring Plan DOE/WIPP-99-2194, Rev. 3}

into one common evaporation pond (Evaporation Pond A). Evaporation Pond A discharges to either Evaporation Pond B and/or Evaporation Pond C. The sewage treatment facility is operated in accordance with a discharge permit (DP-831) issued by the New Mexico Environment Department. DP-831 outlines operating, monitoring and closure requirements.

As specified in DP-831 and described in WP 02-EM1001, Sewage Lagoon and Infiltration Controls Sampling, water samples of the influent from the settling pond and each of the two final evaporation ponds ( $\mathrm{B}$ and $\mathrm{C}$ - provided there is water in both) are collected semiannually. Samples of the influent are analyzed for nitrate $\left(\mathrm{NO}_{3}\right)$, total Kjeldahl nitrogen (TKN), TDS, and radiochemistry (Table 5-2). The evaporation ponds are sampled for TDS and radiochemistry $\left({ }^{238} \mathrm{Pu},{ }^{239 / 240} \mathrm{Pu},{ }^{241} \mathrm{Am},{ }^{234} \mathrm{U},{ }^{235} \mathrm{U},{ }^{238} \mathrm{U}\right.$, and $\left.{ }^{90} \mathrm{Sr}\right)$.

The H-19 Evaporation Pond is a single, synthetically lined evaporation pond used for the treatment of nonhazardous waste water collected from sources such as purged groundwater during water quality sampling program (WQSP) well sampling, water collected from the exhaust shaft ventilation system, and other sources at the WIPP site. The operation, maintenance, monitoring, and closure of the evaporation pond is included in the discharge permit. The H-19 Evaporation Pond is sampled for TDS and radiochemistry.

\subsubsection{Effluent Monitoring - Liquid Releases}

DOE Order 5400.5 sets dose limits and requires monitoring of liquid effluent streams. The Environmental Regulatory Guide for Radiological Effluent Monitoring and Environmental Surveillance (DOE, 1991) sets the standard for meeting the requirements of DOE Order 5400.5 . Liquid effluent monitoring is necessary to quantify radionuclides released to the environment and to alert operators of process inconsistences and malfunctions of emission controls.

There is no direct connection between the WHB and the sewage treatment system; therefore, there is no direct pathway for radioactive or hazardous contaminants associated with the TRU wastes to enter the WIPP sewage treatment system. There is a sump in the WHB that collects liquids from throughout the WHB. Should there ever be liquid accumulation in the sump, the water in the sump may be sampled and analyzed for contamination as shown in Table 5-2. The waste would then be characterized and disposed of in accordance with applicable regulations.

\subsubsection{Biotic Sampling}

In accordance with WP 02-EM1011, Biotic Sampling, collection and analysis of biotic samples accomplishes the following:

- $\quad$ Evaluates the potential radiation doses received by way of human consumption

- $\quad$ Predicts the possible concentrations in available biota 


\section{Waste Isolation Pilot Plant Environmental Monitoring Plan DOE/WIPP-99-2194, Rev. 3}

Monitors trends in environmental contamination and possible long-term accumulation of radionuclides

In accordance with WP 02-EM1019, Vegetation Sampling, vegetation samples are collected from the locations where air samples and soil samples are collected (Figure 5-2). In addition, if vegetable gardens are grown at local ranches, a leafy vegetable sample may be collected and analyzed annually.

DOE/EH-0173T (DOE, 1991) indicates that game birds and mammals hunted locally should be sampled during the hunting season near (within $25 \mathrm{~km}$ ) the site. Quail are collected annually, and rabbits are collected on an as-available basis. Quail are trapped at the facility, while rabbits are collected when found on roads near the WIPP site. A composite sample of muscle tissue from each type of animal is collected. Organ tissue is also collected as available. These samples are analyzed as shown in Table 5-2.

Beef and deer samples are collected on an as-available basis, primarily through livestock and vehicle collisions on the roads in the WIPP vicinity. Tissue and organ samples are collected only if they are easily attainable.

Catfish are collected annually from the Pecos River near Carlsbad; from Brantley Lake, which is located on the Pecos River between Artesia and Carlsbad, and from Pierce Canyon (Pecos River near Malaga). The samples are composited by location and then analyzed for the specific radionuclides indicated in Table 5-2.

Each sample is collected as specified in WP 02-EM1011. Sufficient material is collected to meet the needs of the analytical laboratory.

\subsubsection{Soil Sampling}

Soil samples are collected annually from the six locations shown in Figure 5-2. Sampling sites are co-located at air particulate sampling locations and the vegetation sampling sites as recommended in HASL-300, Environmental Measurement Laboratory Procedures Manual (DOE, 1997) and DOE/EH-0173T (DOE, 1991). The frequency of sampling also follows the guidance contained in DOE/EH-0173T for obtaining long-term accumulation trends. Samples are currently being collected at depths of $0-2,2-5$, and 5-10 cm. The soil samples are analyzed as indicated in Table 5-2.

\subsubsection{Surface Water Sampling}

Surface water is absent within the WIPP Land Withdrawal Area. As specified in WP 02-EM1017, Surface Water and Sediment Sampling for Radiological Analysis, the surface water samples are collected annually from up to 14 locations, as available, in the WIPP vicinity specified in Figure 5-3. These locations comprise the major bodies of surface water in the WIPP vicinity and provide adequate data concerning the surface water pathway. Analyses are performed as specified in Table 5-2. 


\section{Waste Isolation Pilot Plant Environmental Monitoring Plan DOE/WIPP-99-2194, Rev. 3}

Drinking water is sampled as "surface water" at the pump house from the WIPP water supply system once per year. This is the facility which receives/stores the fresh water that is supplied to the site. This water is sampled annually and analyzed for the constituents listed in Table 5-2.

\subsubsection{Sediment Sampling}

In accordance with WP 02-EM1017, Surface Water and Sediment Sampling for Radiological Analysis, sediment samples are collected from near the WIPP site annually (Figure 5-6) and analyzed for specific radionuclides noted in Table 5-2. On the Pecos River there are four locations: the upper Pecos near Artesia, New Mexico, Brantley Lake State Park, Lake Carlsbad recreational park, and Pierce Canyon. Eight dirt tanks (earthen catchment basins) are used by area ranchers to collect runoff water for livestock. These tanks are Tut, Noya, Red, Indian, Lost, Bottom-of-the-Hill, Poker Trap, and Hill. Samples are taken from the sewage lagoon outflow when sediment buildup is adequate for sampling purposes. The analytical results for the sediment sample analysis are reported annually in the ASER (DOE, 2007).

\subsubsection{Groundwater Sampling}

Groundwater, which may potentially be affected by DOE operations, must be monitored to detect and document the effects of such operations on groundwater quality and quantity, and to show compliance with applicable federal and state laws and regulations. The groundwater monitoring programs are conducted on-site and near DOE facilities to:

- $\quad$ Obtain data to determine baseline conditions of groundwater quality and quantity.

- Demonstrate compliance with and implementation of applicable regulations and DOE orders.

- $\quad$ Provide data for the early detection of groundwater contamination.

- $\quad$ Identify existing and potential groundwater contamination sources and maintain surveillance of these sources.

- $\quad$ Provide data upon which decisions can be made concerning land disposal practices and the management of groundwater resources.

Though listed under the radiological program, the Groundwater Monitoring Program also supports the detection monitoring program as mandated by 20.4.1 New Mexico Administrative Code and the EPA Compliance Certification Application (DOE, 1996) as mandated by 40 CFR Part 194, "Criteria for the Certification and Recertification of the Waste Isolation Pilot Plant's Compliance with the 40 CFR Part 191 Disposal Regulations." These requirements dictate a broader set of nonradiological parameters for measurement. The groundwater monitoring program consists of two subprograms, the groundwater level monitoring program and the WQSP. 


\section{Waste Isolation Pilot Plant Environmental Monitoring Plan DOE/WIPP-99-2194, Rev. 3}

The groundwater level monitoring program involves collecting monthly water level measurements from available wells (Figure 5-4) near WIPP. Groundwater surface elevations are monitored on a monthly basis to supplement the area water-level database and to help define regional changes in groundwater flow directions and gradients. These data are reported in the ASER. Groundwater level measurement is performed in accordance with WP 02-EM1014, Groundwater Level Measurement. Collection of groundwater-level data assists the DOE in meeting performance assessment, regulatory compliance, and permitting requirements.

The WQSP groundwater samples are collected from the wells noted on Figure 5-5. Both serial and final samples are collected. Serial samples are taken at regular intervals and analyzed in the mobile field laboratory for various physical and chemical parameters, called field indicator parameters. The serial sample data are used to determine whether the sample is representative of undisturbed groundwater as a direct function of the volume of water being purged from the well. Protocols for serial sample analysis are contained in WP 02-EM1005, Groundwater Serial Sample Analysis. Final samples are collected when the groundwater being purged from the well has been determined to have reached a representative state. The final samples are sent to analytical laboratories for analysis of chemical and physical parameters as well as specific radionuclides. The protocols for the collection of final and serial samples are contained in WP 02-EM1006, Final Sample and Serial Sample Collection.

Water quality sampling is performed semiannually in seven wells at WIPP. WQSP-1 through WQSP-6 are completed in the Culebra Member of the Rustler Formation, and WQSP-6a is completed in the Dewey Lake Formation. The wells are constructed to EPA standards, modified to accommodate the low-water production rates in the formations, and to meet the detection monitoring standards under the WIPP Hazardous Waste Facility Permit (HWFP) \#NM4890139088-TSDF (New Mexico Environment Department, 1999). The analytical results for samples collected from the WQSP wells are reported in semiannual groundwater monitoring reports and in the ASER.

\subsection{Nonradiological Environmental Monitoring}

Nonradiological environmental monitoring activities at WIPP consist of a comprehensive set of sampling programs designed to detect and quantify impacts of construction and operational activities. The requirements and objectives of both preoperational and operational nonradiological environmental monitoring are described in the WIPP FEIS (DOE, 1980). The ecological monitoring program focuses on nonradiological effects, which are ongoing.

Section 2.5 of Appendix $\mathrm{J}$ of the WIPP FEIS states:

The operational ecological monitoring program, building on the foundation established through preoperational ecological monitoring, will document the ecological effects of construction and operation . . . and will focus primarily on indicator organisms and selected abiotic parameters. 


\section{Waste Isolation Pilot Plant Environmental Monitoring Plan DOE/WIPP-99-2194, Rev. 3}

Primary guidance for ecological monitoring was derived from the WIPP FEIS and the American Institute of Biological Scientists evaluation of the WIPP biology program. Table 5-2 lists parameters that will be monitored for evidence of possible site impacts. Results of these studies are published in the ASER.

\subsubsection{Meteorological Monitoring}

DOE/EH-0173T (DOE, 1991) provides guidance on how each DOE site is to establish a meteorological monitoring program appropriate for the activities at the site and for the local topography and demography. Meteorological parameters are monitored and recorded to supplement characterization of the local environment and facilitate the interpretation of data from other environmental monitoring activities at WIPP. The WIPP meteorological program is performed in accordance with the Meteorological Quality Assurance Plan (WP 02-EM.01), which was written in accordance with the guidance contained in Meteorological Monitoring Guidance for Regulatory Modeling Applications (EPA, 2000).

The meteorological monitoring station is a 50-meter tower located northeast of the WIPP Property Protection Area. Temperature, wind speed, and wind direction are monitored at 2, 10, and 50 meters (16, 33, and 165 feet, respectively); barometric pressure, humidity, solar radiation, and precipitation are also monitored at this location. Measurements are recorded at the central monitoring system, which tracks numerous real-time parameters on a centralized computer system.

\subsubsection{Volatile Organic Compound Monitoring}

A repository volatile organic compound (VOC) monitoring program was implemented in accordance with Attachment N of the WIPP HWFP when the HWFP became effective on October 27, 1999. The monitoring program is used to determine VOC concentrations attributed to open and closed waste disposal panels. Nine compounds are monitored under the program.

The repository VOC monitoring program measures VOC concentrations in the ambient air to determine releases from open and closed panels located at WIPP. Ambient air samples are collected at two locations in the underground. The upstream location (VOC B) measures VOC concentrations attributable to background sources of VOCs. The downstream location (VOC A) measures upstream sources of VOCs and VOC releases from the panels. The differences between the two locations represent the measure of VOCs released from open and closed panels.

In October 2006, a disposal room VOC monitoring program was added to the HWFP. This program is used to determine the concentration of VOCs in open and closed disposal rooms in open waste panels. In order to do this, samples are collected in each disposal room within an active panel that is receiving waste. Two locations are sampled in each closed room until panel closure activities are initiated. 


\section{Waste Isolation Pilot Plant Environmental Monitoring Plan DOE/WIPP-99-2194, Rev. 3}

VOC sampling is performed using guidance included in Compendium Method TO-15, Determination of Volatile Organic Compounds (VOCs) in Air Collected in SpeciallyPrepared Canisters and Analysis By Gas Chromatography /Mass Spectrometry (GC/MS) (EPA, 1999) as a basis. Analysis of the samples is performed by an outside laboratory using concepts found in both TO-15 and the draft EPA Contract Laboratory Program Volatile Organics Analysis of Ambient Air in Canisters (EPA, 1994).

In February 2008, a requirement for closed room hydrogen and methane monitoring was added to the HWFP. The HWFP requires that every room in a closed (inactive) panel be monitored on the inlet and exhaust of each closed rooms. In addition to the closed room locations, monitoring will occur on each side of the restrictive substantial barrier. In all, each closed (inactive) panel has 18 hydrogen and methane monitoring locations. The hydrogen and methane samples are analyzed using gas chromatography and thermal conductivity detection.

\subsubsection{Groundwater Surveillance}

The WIPP groundwater monitoring program was described in Section 5.2.9. Table 5-2 indicates the nonradiological groundwater parameters monitored using standard wet chemistry analytical methods. These methods are used to analyze for standard primary constituents such as chlorides, magnesium, calcium, and sulfates. In addition to the general chemistry analysis, data are also gathered for constituents listed in Module $\mathrm{V}$ of the HWFP. Constituents listed in Module V include metals, purgable volatile compounds, non-purgable volatile compounds, and semivolatile compounds.

\subsubsection{WIPP Shallow Subsurface Water Monitoring}

The objective of the WIPP SSW program is to establish, by means of water level monitoring and water sampling and analysis, accurate and representative data in support of DP-831. This program documents the SSW quality through time to determine the effectiveness of source control measures. Water levels are taken from the wells in Figure 5-7, and samples are taken from ten of these wells. Water levels from the SSW program wells are taken quarterly and water samples are obtained semiannually.

General chemistry of the SSW is monitored for parameters expressed in the DP-831 permit, using standard wet chemistry analytical methods. Analysis is performed for the parameters in Table 5-2. Additionally, field indicator parameters are temperature, conductivity, and $\mathrm{pH}$.

\subsubsection{Surface Water Monitoring}

Infiltration controls have been constructed in accordance with DP-831 to minimize the infiltration of storm water runoff. These include Evaporation Basin A, Pond 1, Pond 2, the Salt Storage Extension Cells A and B, the Salt Storage Extension Evaporation Basin, the Salt Pile Evaporation Pond and berms and ditches associated with these structures. As specified in DP-831 and WP 02-EM1001, water samples are collected 


\section{Waste Isolation Pilot Plant Environmental Monitoring Plan \\ DOE/WIPP-99-2194, Rev. 3}

once per year after a storm event from the Salt Pile Evaporation Pond, Salt Storage Extension Evaporation Basin, Evaporation Basin A, Pond 1, and Pond 2. Samples are analyzed as shown in Table 5-2.

\section{$5.4 \quad$ Land Management}

Parties who desire to conduct activities that affect lands under the jurisdiction of the DOE outside the Property Protection Area are required to prepare a land use request (LUR). An LUR consists of a narrative description of the project, a completed environmental review, and a map depicting the location of the proposed activity. The LUR is used to determine if applicable regulatory requirements have been met before the approval of a proposed project. An LUR is submitted to the land use coordinator by any organization wishing to complete any construction, rights-of-way, pipeline easements, or similar actions within the WIPP site boundary and on lands used in the operation of WIPP, under the jurisdiction of the DOE.

\subsection{Oil and Gas Surveillance}

Surveillance of oil and gas activities within one mile of the WIPP boundary is conducted in accordance with the U.S. Bureau of Land Management/DOE memorandum of understanding. Oil and gas activities within the defined land sectors are monitored twice monthly to identify new activities associated with oil and gas exploration/ production, including:

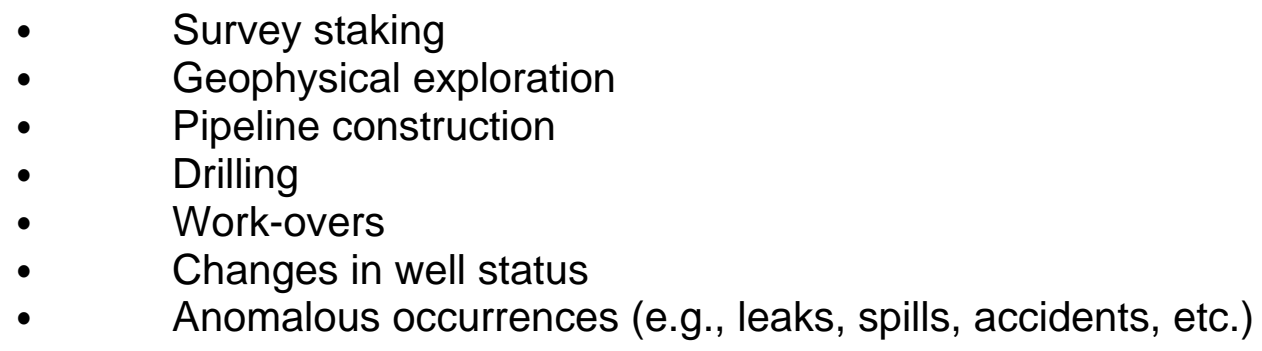

Data from this activity are used to update drilling parameters that are used as part of the WIPP performance assessment dataset. In addition, observations of drilling activities adjacent to the WIPP site boundary are used to determine that no driller intrudes into the Land Withdrawal Area. 
Waste Isolation Pilot Plant Environmental Monitoring Plan DOE/WIPP-99-2194, Rev. 3

\begin{tabular}{|c|c|c|c|}
\hline \multicolumn{4}{|c|}{ Table 5-1 - Environmental Monitoring Sampling ${ }^{1}$} \\
\hline Program & Type of Sample & $\begin{array}{l}\text { Number of } \\
\text { Sampling } \\
\text { Locations }\end{array}$ & Sampling Frequency \\
\hline \multirow[t]{11}{*}{ Radiological } & Airborne effluent & 3 & Periodic/confirmatory \\
\hline & Airborne particulate & 7 & Weekly \\
\hline & $\begin{array}{l}\text { Sewage treatment system } \\
(\mathrm{DP}-831)^{2}\end{array}$ & 3 & Semiannual \\
\hline & $\mathrm{H}-19(\mathrm{DP}-831)^{2}$ & 1 & Semiannual \\
\hline & Liquid effluent & 1 (WHB sump) & If needed \\
\hline & \multicolumn{3}{|l|}{ Biotic } \\
\hline & $\begin{array}{ll}\text { - } & \text { Quail } \\
\text { - } & \text { Rabbits } \\
\text { - } & \text { Beef/Deer } \\
\text { - } & \text { Fish } \\
\text { - } & \text { Vegetation }\end{array}$ & $\begin{array}{l}\text { WIPP vicinity } \\
\text { WIPP vicinity } \\
\text { WIPP vicinity } \\
3 \\
6\end{array}$ & $\begin{array}{l}\text { Annual } \\
\text { As available } \\
\text { As available } \\
\text { Annual } \\
\text { Annual }\end{array}$ \\
\hline & Soil & 6 & Annual \\
\hline & Surface water & Maximum of 14 & Annual \\
\hline & Sediment & $\begin{array}{l}\text { Maximum of } 12 ; \\
13 \text { if sediment is } \\
\text { present at sewage } \\
\text { lagoon outfall }\end{array}$ & Annual \\
\hline & Groundwater & 7 & Semiannual \\
\hline \multirow[t]{7}{*}{ Nonradiological } & Meteorology & 1 & Continuous \\
\hline & \multicolumn{3}{|l|}{ Volatile organic compounds } \\
\hline & $\begin{array}{ll}\text { - } & \text { VOCs - Repository } \\
\text { - } & \text { VOCs - Disposal Room }\end{array}$ & $\begin{array}{c}2 \\
\text { \# of active panel } \\
\text { disposal rooms }\end{array}$ & $\begin{array}{l}\text { Semiweekly } \\
\text { Bi-weekly }\end{array}$ \\
\hline & Hydrogen/Methane & $\begin{array}{l}18 \text { per inactive } \\
\text { panel }\end{array}$ & Monthly \\
\hline & Groundwater & 7 & Semiannual \\
\hline & Shallow subsurface water & Maximum of 10 & Semiannual \\
\hline & Surface water (DP-831) & 5 & $\begin{array}{l}\text { After a storm major event } \\
\text { or annually, whichever is } \\
\text { more frequent }\end{array}$ \\
\hline
\end{tabular}

${ }^{1}$ The number of certain types of samples taken can be driven by site conditions. For example, during dry periods there may be no surface water or sediment to sample at certain locations. Likewise, the number of samples for biota will also vary. For example, the number of rabbits available as samples of opportunity will vary as will fishing conditions that are affected by weather and algae levels in the water.

${ }^{2}$ Includes a nonradiological program component. 
Waste Isolation Pilot Plant Environmental Monitoring Plan

DOE/WIPP-99-2194, Rev. 3

\begin{tabular}{|l|l|}
\hline \multicolumn{2}{|c|}{ Table 5-2 - EMP Analytical Array } \\
\hline Type of Sample & Analysis \\
\hline Effluent - Liquid Release & (1) Specific radionuclides \\
\hline $\begin{array}{l}\text { DP-831 (Sewage Lagoon and } \\
\text { H-19 Evaporation Pond) }\end{array}$ & $\begin{array}{l}\mathrm{NO}_{3}, \mathrm{TKN}, \mathrm{TDS},{ }^{238} \mathrm{Pu}^{239 / 240} \mathrm{Pu},{ }^{241} \mathrm{Am},{ }^{234} \mathrm{U}^{235} \mathrm{U}^{238} \mathrm{U}, \text { and }{ }^{90} \mathrm{Sr} \\
\text { (Sewage Lagoons influent) }\end{array}$ \\
\hline TDS and radionuclides only (H-19 Evaporation Pond)
\end{tabular}

(1) Specific radionuclides: ${ }^{241} \mathrm{Am},{ }^{60} \mathrm{Co},{ }^{137} \mathrm{Cs},{ }^{40} \mathrm{~K},{ }^{238} \mathrm{Pu},{ }^{239 / 240} \mathrm{Pu},{ }^{90} \mathrm{Sr},{ }^{234} \mathrm{U},{ }^{235} \mathrm{U},{ }^{238} \mathrm{U}$, gross alpha, and gross beta.

(NOTE: Gross alpha and gross beta are only analyzed in the air samples.)

(2) Chemical analysis: antimony, arsenic, barium, beryllium, cadmium, calcium, chloride, chromium, chloroform, cresols, nickel, thallium, vinyl chloride, total organic halogen, total organic carbon, 1,1-dichloroethylene, 1,1-dichloroethane, 1,2-dichloroethane, chlorobenzene, 1,2-dichlorobenzene, 1,4-dichlorobenzene, hexachloroethane, hexachlorobenzene, isobutanol, iron, lead, magnesium, mercury, nitrobenzene, potassium, selenium, silver, carbon tetrachloride, toluene, methylene chloride, pyridine, pentachlorophenol, 2,4-dinitrophenol, 2,4-dinitrotoluene, tetrachloroethylene, 1,1,2,2-tetrachloroethane, methyl ethyl ketone, trichlorofluoromethane, trichloroethylene, 1,1,1-trichloroethane and 1,1,2-trichloroethane, xylenes, cis-1, 2-dichloroethylene, (trans) -1, 2-dichloroethylene, vanadium, sulfate, sodium, and alkalinity.

(3) Physical properties: pH, specific conductance, TDS, density, and total suspended solids.

(4) Title 40 CFR Part 264, "Standards for Owners and Operators of Hazardous Waste Treatment, Storage, and Disposal Facilities" - specific target compounds of Appendix IX for analysis in groundwater samples 


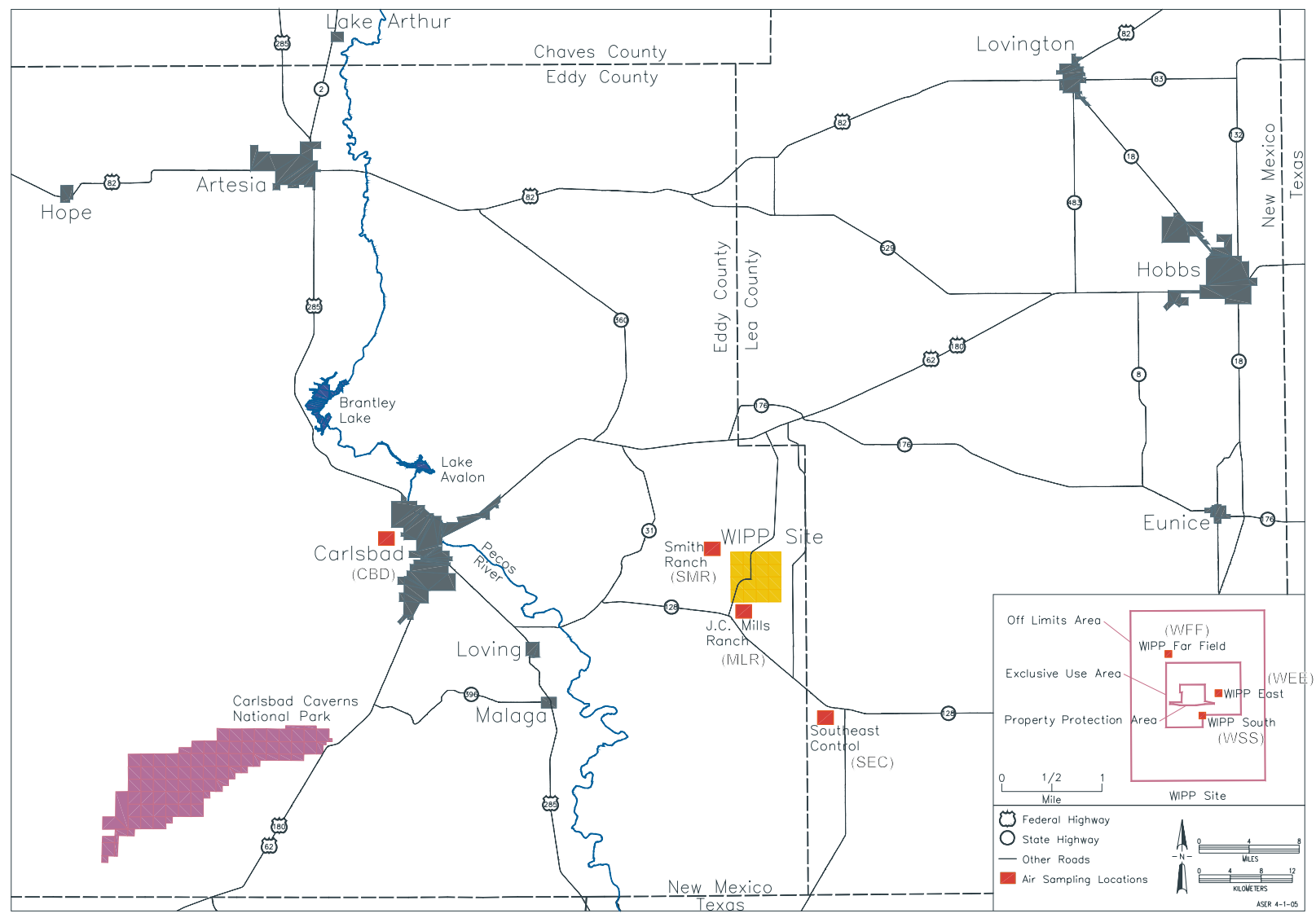

Figure 5-1 - Air Sampling Sites 


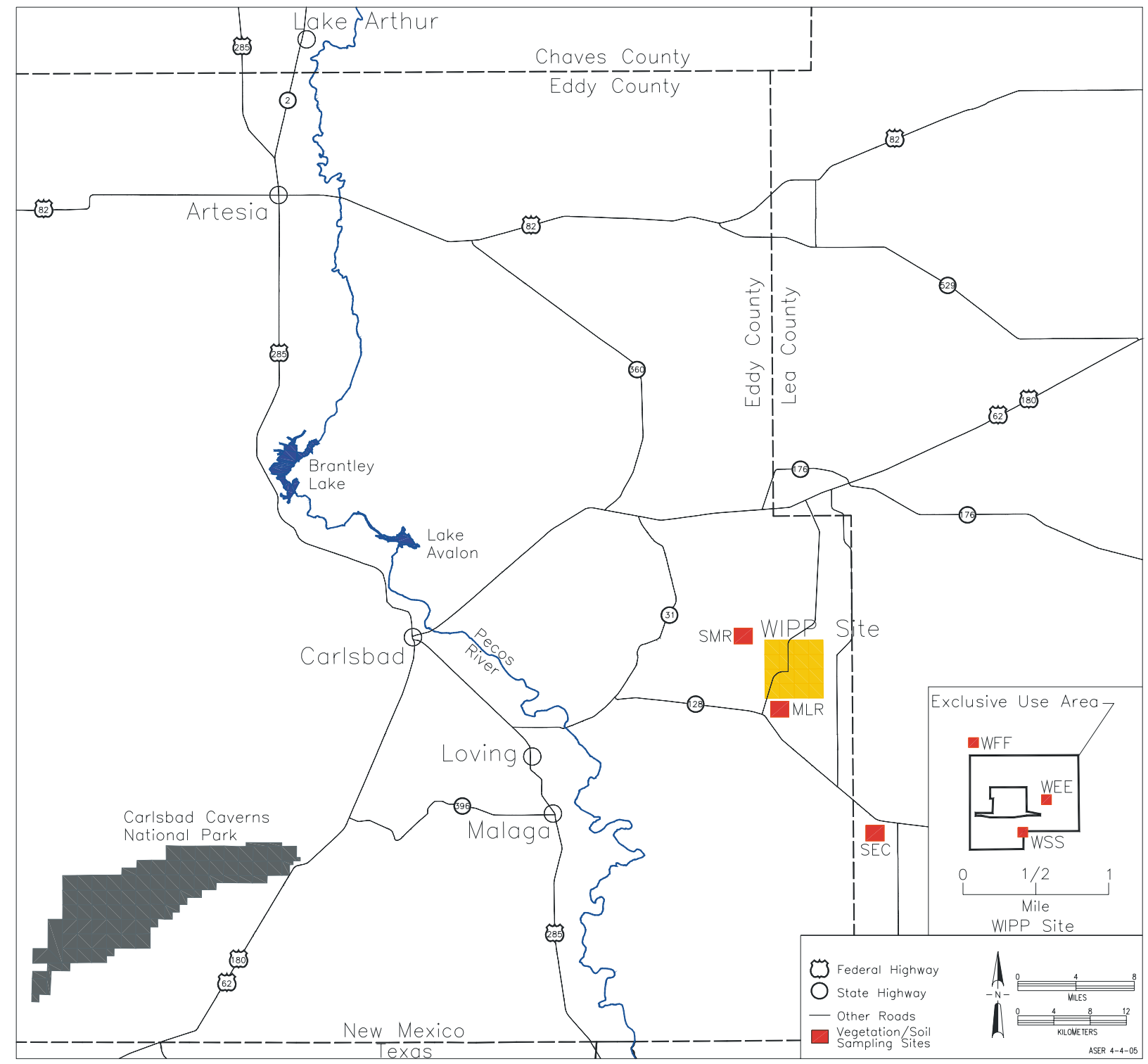

Figure 5-2 - Vegetation/Soil Sampling Sites 


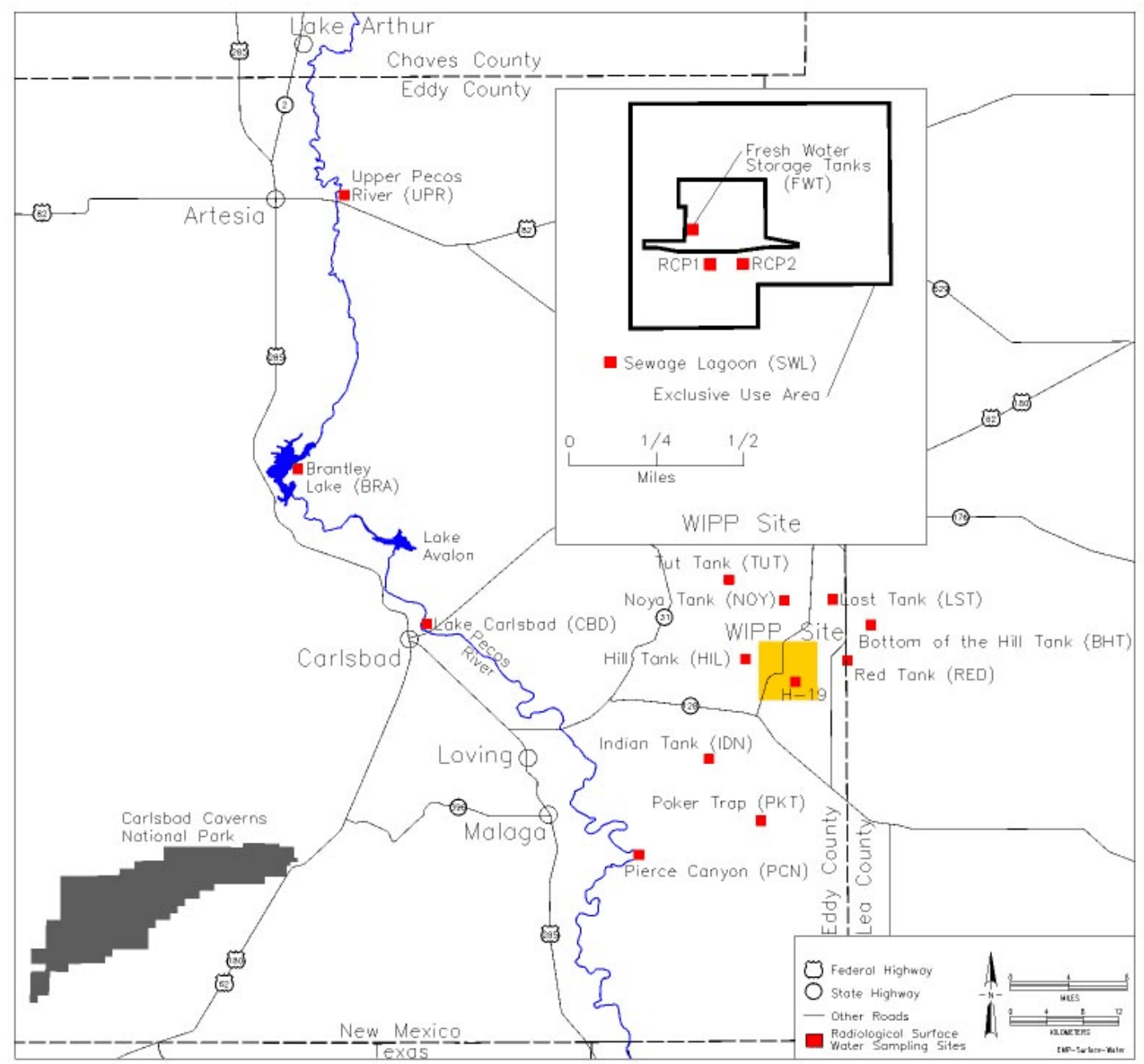

Figure 5-3 - Surface Water Sampling Sites 


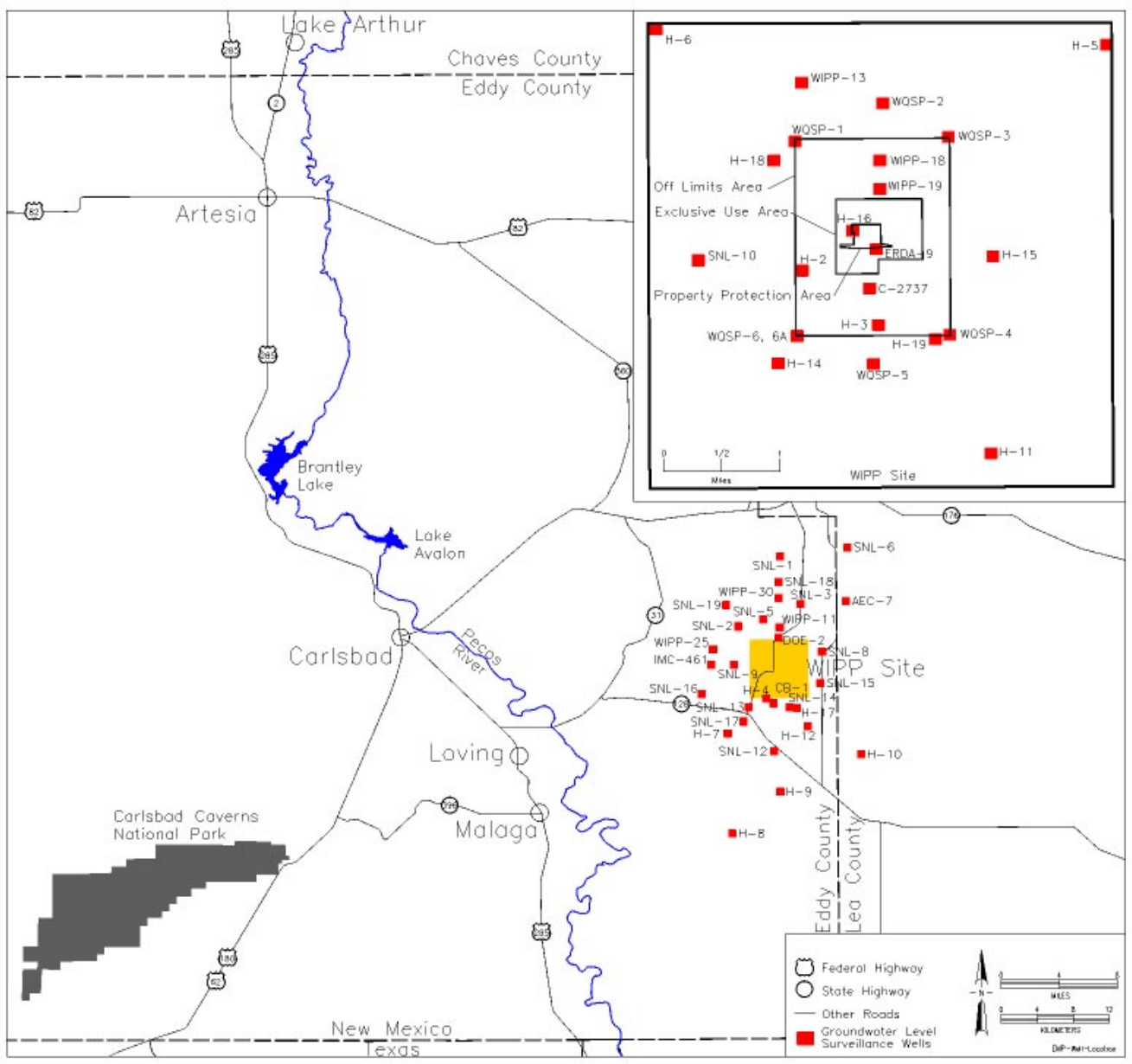

Figure 5-4 - Groundwater Level Surveillance Wells 


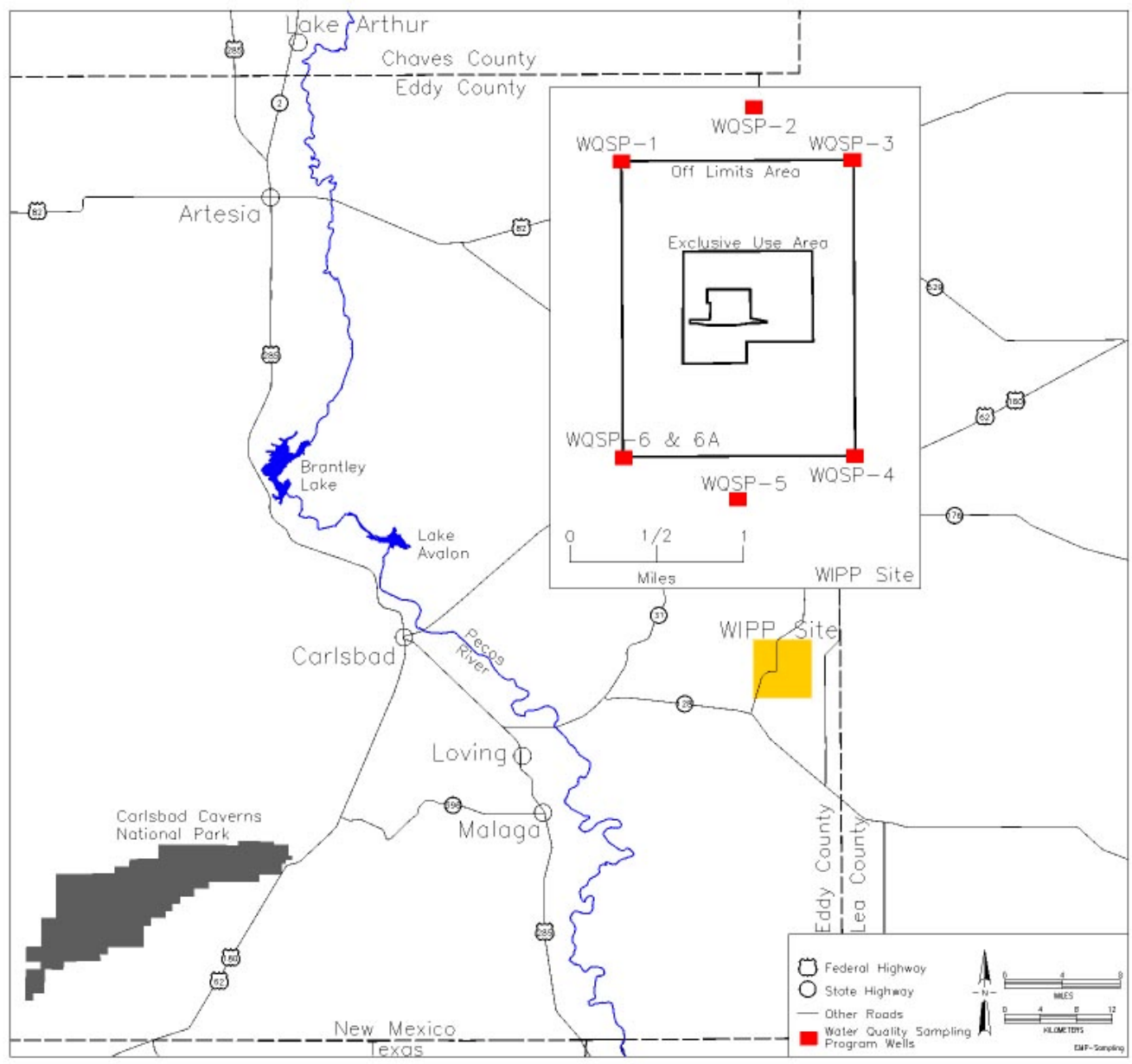

Figure 5-5 - Groundwater Sampling Locations 


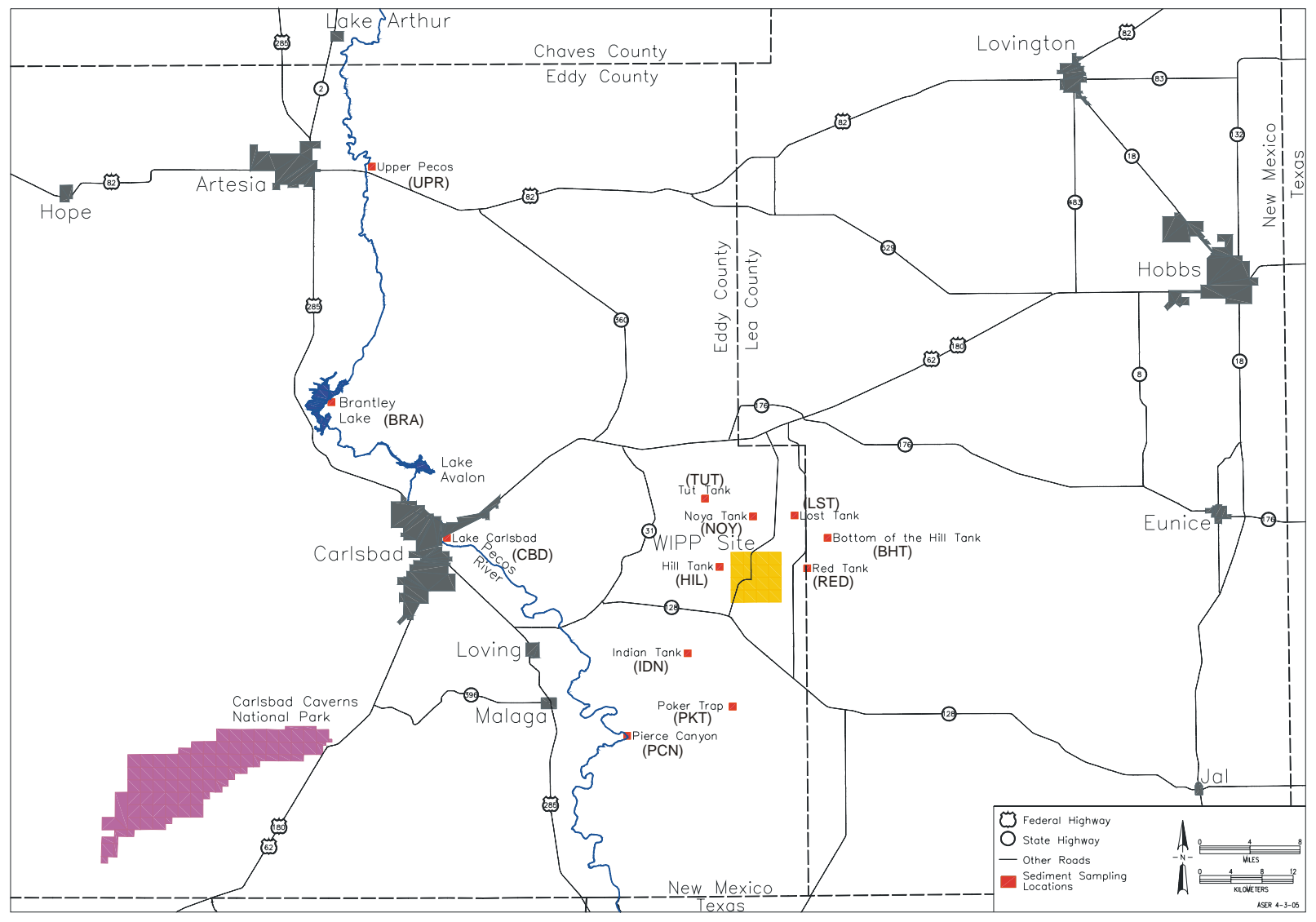

Figure 5-6 - Sediment Sampling Sites 


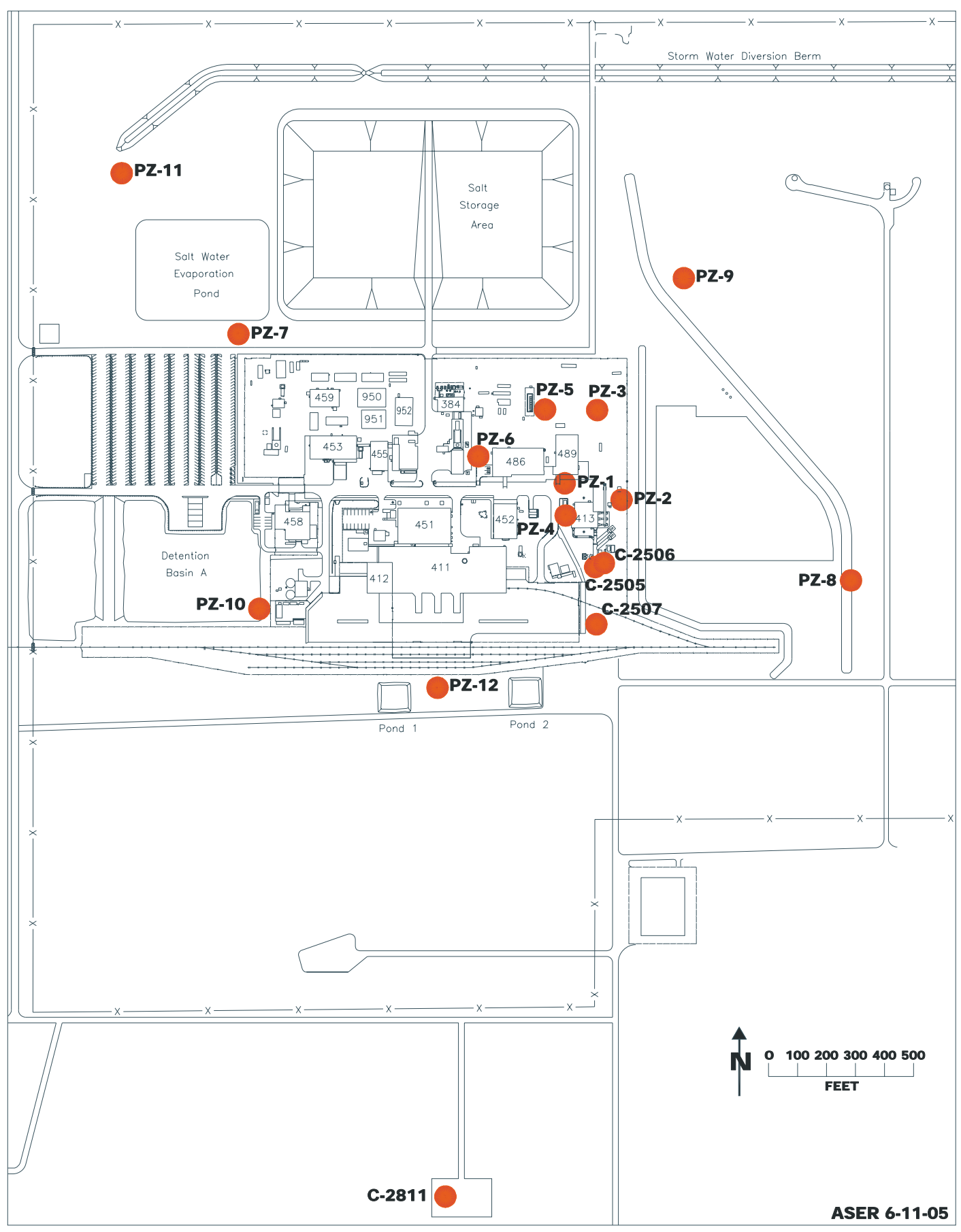

Figure 5-7 - Locations of SSW Wells (Piezometers PZ-1 through 12; Wells C-2811, C-2505, C-2506, and C-2507) 


\subsection{DATA ANALYSES}

This section describes the statistical methods used for analyzing data collected in the environmental monitoring program. The goal of statistical data analyses is to provide an objective and reliable means for comparing measurements to the objectives of the data collection program, typically to determine whether the data indicate compliance with limits.

The data results of the sample media may be graphed by analyte to evaluate analytical consistency presented in a time trend plot. Should a discrepancy be noted during this review, an in-depth evaluation can be performed to identify the source of the deviation (i.e., statistical outlier or analytical technique). This is particularly useful with the Detection Monitoring Program results.

Data analysis is required for each parameter before a statistically valid interpretation can be achieved. Five general levels of data analysis are described here. Data analysis at each of these levels is considered for each parameter. The levels are:

(1) Determination of accuracy for each point measurement by quantification and control of precision and bias

(2) Evaluation of the effects of correlation on the expected value of the point measurement due to location and time of sampling

(3) Identification of the appropriate model of variability (i.e., a probability density distribution) for each point measurement and the calculation of descriptive statistics based on the chosen model

(4) Treatment of data anomalies

(5) Interpretation of data through statistically valid comparisons (tests) and trend analysis

Each of these levels of data analysis is described below and with the requirements for application to the EMP.

\subsection{Accuracy}

Accuracy is the closeness of a measurement to its actual, or true, value. Since the true value cannot be determined independently, accuracy cannot be absolutely determined. However, accuracy is controlled by two basic elements: bias (consistent over- or under-estimation of the true value) and precision (concentration of repeated measurements around a central [expected] value). Accuracy is maximized when bias is minimized and precision is maximized. 


\section{Waste Isolation Pilot Plant Environmental Monitoring Plan DOE/WIPP-99-2194, Rev. 3}

To some extent, precision and bias are controlled by strict adherence to sample collection, handling, and measurement protocols. Environmental monitoring procedures specify the protocols for those functions performed at WIPP.

The remaining element of precision and bias is quantitatively estimated through periodic performance of the following measurements:

- $\quad$ Measurement of duplicate samples

- $\quad$ Repeated measurement of the same sample

- $\quad$ Measurement of blank samples

- $\quad$ Measurement of standard spiked samples (samples of an equivalent medium containing a known amount of the target species)

The measurement of duplicate samples is used for assessing precision incurred through the entire process of sample collection, handling, and measurement. Repeated measurements are used to determine the amount of imprecision attributable to measurement. Blanks are analyzed to monitor purity of reagents and any other crosscontamination attributing bias to the sample results during collection of samples and laboratory analysis. Contract laboratories performing WIPP sample analyses may be required to participate in performance evaluation programs and pass the specific criteria set forth for measuring precision and accuracy.

The methods for satisfying these requirements will depend upon the sampling and measurement characteristics of each parameter. Generally, these specifications will be followed:

- $\quad$ One duplicate sample is collected for each ten samples collected.

- One repeated measurement is made for each discrete set of samples analyzed, or for each tenth sample analyzed, whichever is more frequent.

- $\quad$ One blank sample is analyzed for each discrete set of samples analyzed (for radioactivity counts, the background count is not considered a blank).

- $\quad$ Spiked samples are measured.

Variations from these specifications may be required due to peculiarities of the individual parameters and are stated in the analysis for that parameter.

\subsection{Temporal and Spatial Analysis}

Environmental parameters vary with space and time. The effect of one or both of these two factors on the expected value of a point measurement is statistically evaluated through spatial analysis and time series analysis; however, these methods often require 


\section{Waste Isolation Pilot Plant Environmental Monitoring Plan DOE/WIPP-99-2194, Rev. 3}

extensive sampling efforts that are in excess of the practical requirements of the WIPP program. The application of these methods to a particular parameter must, therefore, be limited by consideration of its significance in the final interpretation of the data.

In particular, spatial analysis has limited use in this program, although the effect of spatial correlation on the interpretation of the data is considered for each parameter. Spatial variability is accounted for by the use of predetermined key sampling locations. Data analysis is performed on a location-specific basis, or data from different locations are combined only when the data are considered to be statistically homogeneous.

Time series analysis plays a more important role in data analysis for the EMP. Parameters may be reported as time series, either in tabular form or plots. For key time series parameters, these plots are in the form of control charts on which control limits will be identified based on the preoperational database, fixed standards, control location databases, or other standards for comparison.

\subsection{Distributions and Descriptive Statistics}

Descriptive statistics may be calculated for homogeneous data sets. These would include a central value and a standard deviation. The central value is the mean of the data. The standard deviation is calculated and used as a basis for the reported range in variation. Typically, \pm 2 standard deviations from the mean are plotted on the graphs.

\subsection{Data Anomalies}

Historical data and/or trend charts are maintained on parameters and constituents for which analysis is performed in the Detection Monitoring Program. The historical databases with established control limits at the 95 percent confidence level (or \pm 2 standard deviation from the mean) are used in identifying an outlier. The 95 percent confidence level means that 5 percent, or one out of 20 , normal results are expected to fall outside the limits. For analytical measurements reported as "nondetect" or below the method detection limit, the practical quantitation limit (which is between three and ten times the method detection limit) is set as the upper threshold. An investigation is prompted by reviewing the sampling process and verifying that the data quality objectives were met. The data are qualified accordingly and documented when the analytical results indicate matrix contamination, method problems encountered during analysis, or an inconsistent sampling is identified. All analytical results are included in the charts, but excluded in establishing control limits if a known error has been identified. Including outliers in calculating control limits generates a range of values too broad or too small.

\subsection{Data Comparisons}

Comparisons between data sets may be performed using standard statistical tests. The selection of the specific test is dependent upon the relative power of the test and the degree to which the underlying requirements of the test are met. In addition to tests comparing data from distinct locations and times, trend analyses may be performed on 


\section{Waste Isolation Pilot Plant Environmental Monitoring Plan DOE/WIPP-99-2194, Rev. 3}

time series where sufficient data exist. A 95 percent confidence level will be used for the final interpretation of Detection Monitoring Program results. A 99 percent confidence level may be used for the radiological monitoring program.

\subsection{Laboratory Procedures}

Environmental sampling and analytical laboratory procedures used to obtain quality results for WIPP are contained and/or described in the following documents:

- $\quad$ WIPP Groundwater Monitoring Program Plan (WP 02-1)

- $\quad$ The environmental monitoring procedures of the WP 02-EM series

- $\quad$ The VOC monitoring procedures of the WP 12-VC series

- $\quad$ Radiochemistry Quality Assurance Plan (WP 12-RL.01)

- Washington TRU Solutions LLC Quality Assurance Program Description (WP 13-1)

WIPP has analytical capabilities as well as subcontracted analytical support. Each laboratory is responsible for maintaining an approved QA program for each of the programs discussed in Section 5.0.

\subsection{Sample Handling}

Sample Identification and Tracking

There is a sample identity code used to uniquely identify environmental samples collected. The code contains sample-specific information used to accurately identify sample type, sample location, date, and sequence of sampling event. A detailed description of the sample identification for radiological and nonradiological samples, including sample identification, calculations, computer inputs, and other applicable reviews, are described in environmental sampling procedures. Field data sheets are also maintained in accordance with procedures. The sample tracking is performed from "cradle to grave."

\section{Sampling Schedule}

The sample type, location, and frequency of collection are noted in Table 5-1. The sampling schedule at WIPP is based on waste composition, climate, and demography.

\section{Environmental Activity Levels}

During operations, TRU wastes will remain in sealed containers. Therefore, radionuclide levels in environmental samples are expected to remain at background during operations. Environmental samples are collected in accordance with accepted 


\section{Waste Isolation Pilot Plant Environmental Monitoring Plan DOE/WIPP-99-2194, Rev. 3}

practices and widely recognized methodologies and criteria for environmental monitoring (e.g., the environmental monitoring procedures of the WP 02-EM series).

\section{Packaging and Shipping of Samples Off-Site}

Environmental samples sent off-site for analysis are packaged and shipped in accordance with transportation regulations and specific sampling procedures (i.e., soil, water, vegetation, etc.) listed in the environmental monitoring procedures of the WP 02-EM series. These procedures outline the chain-of-custody requirements that ensure the integrity of samples. WIPP does not handle high-activity samples in the environmental monitoring programs. Contract laboratories are required to follow QA/QC procedures to ensure that cross-contamination between high and low activity samples will not occur.

The laboratory must be approved through a WTS evaluation to be put on the WTS qualified supplier list before proceeding with strict QA laboratory evaluations. The quality of the data from contract analytical laboratories is verified by (1) participation in interlaboratory cross-checks, (2) duplicate and blank sample analysis, and (3) occasional comparison of results from sample splits.

\subsection{QUALITY ASSURANCE}

This section defines the policies and procedures that have been implemented at WIPP to provide confidence in the quality of environmental data. QA practices that cover monitoring activities at WIPP are consistent with applicable elements of the 18-element format in ANSI/ASME [American National Standards Institute/American Society of Mechanical Engineers] NQA-I [Nuclear Quality Assurance] (ANSI, 1989).

WP 13-1 (WTS QAPD) defines QA requirements and responsibilities that apply to WTS. The format of the QAPD is based on the QA criteria of 10 CFR §830.122, "Quality Assurance Criteria." The WTS QAPD also addresses certain EPA QA requirements extracted from the EPA's QA/G-5, Guidance for Preparing Quality Assurance Project Plans (EPA, 2002). The WTS QAPD contains requirements that apply to environmental data operations (i.e., compliance activities associated with collection and analysis of environmental samples, including data reduction, handling, reporting, and records management).

A comprehensive QA program has been implemented to ensure that the data collected are representative of actual concentrations in the environment. Each contract laboratory is responsible for maintaining an approved QA program detailing the following:

- $\quad$ Routine calibration of instruments

- $\quad$ Frequent source and background checks (as appropriate)

- $\quad$ Routine yield determinations of radiochemical procedures 


\section{Waste Isolation Pilot Plant Environmental Monitoring Plan \\ DOE/WIPP-99-2194, Rev. 3}

- Replicate/duplicate analyses to check precision

- $\quad$ Standard and spike analyses to check accuracy

- Expiration of reagents to ensure that chemical purity, which could affect the results of the analytical process, is not compromised

The accuracy of chemical or radiochemistry analysis is ensured through the use of standards traceable to the National Institute of Standards and Technology and participation in a performance evaluation program.

\subsection{Goal}

The WTS QA policy sets a goal to perform all work in such a manner that the required quality is attained or exceeded. To attain this goal, WTS has developed and implemented a formal QA program that is tailored for activities associated with receipt of TRU waste, including operational safety, environmental compliance, and performance assessment.

\subsection{Program Elements/Criteria}

The specific WIPP QA program elements/criteria that are applicable to the EMP are provided in the 10 CFR $\$ 830.122$ criteria. These elements establish the applicable QA requirements that are required for compliance activities associated with the collection and analysis of environmental samples, including data analysis, handling, reporting, and records management.

\subsubsection{Program}

WIPP environmental monitoring and laboratory program documents and statements of work address specific environmental data operations as required by the QAPD. Environmental data operations project descriptions incorporate the following elements, as appropriate:

- Data accuracy (i.e., the degree to which data agree with an accepted reference or true value)

- $\quad$ Data precision (i.e., a measure of agreement between comparable data gathered or developed under similar conditions expressed in terms of a standard deviation)

- Data representativeness (i.e., the degree to which data accurately and precisely represent a characteristic of a population, a parameter, variations at a sample point, or environmental conditions)

- Data completeness (i.e., a measure of the amount of valid data obtained compared to the amount that was expected) 


\section{Waste Isolation Pilot Plant Environmental Monitoring Plan DOE/WIPP-99-2194, Rev. 3}

- $\quad$ Data comparability (i.e., a measure of the confidence with which one data set can be compared to another)

- $\quad$ Data reproducibility (i.e., a measure of the variability among measurements of the same sample by different laboratories)

- $\quad$ Data validation (i.e., a systematic process for reviewing a body of data against a set of criteria to provide assurance that the data are adequate for their intended use)

- $\quad$ Data verification (i.e., a systematic process for reviewing a body of data to verify completeness)

\subsubsection{Personnel Training and Qualification}

The WIPP training program has been designed to ensure that personnel performing work are capable of performing their assigned task proficiently. Personnel who perform work that requires special skills or abilities are required to meet the qualification requirements for that specific task unless directly supervised by a qualified person.

\subsubsection{Quality Improvement}

The quality improvement process has been established and implemented to improve quality and provide corrective action procedures. Corrective action and nonconformance procedures for activities associated with environmental data collection are identified in environmental monitoring and laboratory program documents and statements of work. The following elements are addressed:

- $\quad$ Predetermined limits for data acceptability beyond which corrective action is required

- $\quad$ Process for tracking, verification, and closeout

- $\quad$ Identification of individuals responsible for initiating corrective action and individuals responsible for verifying and approving implementation of the corrective action

Corrective action may be initiated through routine operations, performance audits, system audits, inter/intralaboratory comparison studies, or performance demonstrations conducted by the DOE Carlsbad Field Office.

\subsubsection{Documents and Records}

Procedures are established that control the preparation, review, approval, issuance, use, and revision of documents that establish policies, prescribe work, specify requirements, establish design, or that are being used for the performance of quality-related activities. Procedures are also in place to ensure that records are 


\section{Waste Isolation Pilot Plant Environmental Monitoring Plan DOE/WIPP-99-2194, Rev. 3}

specified, prepared, reviewed, approved, and maintained to accurately reflect completed work. This process is described in WP 15-PR, WIPP Records Management Program. The WIPP records management program provides a project wide records management system that coordinates the collection, maintenance, identification, and preservation of WIPP Project records.

Records generated through environmental monitoring activities are controlled and maintained in accordance with WP 15-PR. This document interprets and implements the records management requirements contained in DOE/CAO 94-1001, Carlsbad Area Office Information Management Plan (DOE, 1994). The document also provides the interpretations and the guidance necessary to meet the records management requirements for the creation, maintenance, use, and disposition of records that document and support the WIPP mission.

Complete, accurate, and auditable environmental monitoring program records will be maintained. The WTS records inventory and disposition schedule will govern environmental monitoring records management.

\subsubsection{Work Processes}

Work is performed to established technical standards and administrative controls. The design of sampling methodology, use of equipment, and required processes are documented and approved. The following requirements for sample design are addressed in environmental monitoring program documents:

- $\quad$ Description of techniques or guidelines used to select sampling sites

- $\quad$ Specific sampling procedures to be used

- $\quad$ Charts, flow diagrams, or tables delineating sampling program operations

- $\quad$ A description of containers, procedures, reagents, etc., used for sample collection, preservation, transportation, and storage

- $\quad$ Special conditions for the preparation of sampling equipment and containers to avoid sample contamination

- $\quad$ Sample preservation methods and holding times

- $\quad$ Time considerations for shipment of samples to the laboratory

- $\quad$ Sample custody or chain-of-custody procedures

- $\quad$ Forms, notebooks, databases, and procedures to be used to document sample history, sampling conditions, and required analyses 


\section{Waste Isolation Pilot Plant Environmental Monitoring Plan \\ DOE/WIPP-99-2194, Rev. 3}

Samples collected for environmental compliance activities or for site validation are controlled by approved chain-of-custody procedures. The actual practices used are documented. The following sample custody procedures are specified in the environmental monitoring program documents.

- $\quad$ For field sampling operations:

- $\quad$ Requirements for preparation of reagents or supplies which become an integral part of the sample

- $\quad$ Forms for recording the location and specific considerations associated with sample acquisition

- $\quad$ Specific sample preservation methods

- $\quad$ Sample labels containing all information necessary for effective sample tracking

- $\quad$ For laboratory operations:

- $\quad$ Identification of responsible party to act as sample custodian at the laboratory facility authorized to sign for incoming field samples, to obtain documents of shipment, and to verify the data entered onto the same custody records

- $\quad$ A laboratory sample custody log consisting of serially numbered standard lab-tracking report sheets

- $\quad$ Specification of laboratory sample custody procedures for sample handling, storage, and disbursement for analysis

Custody records are treated as permanent QA records by the recipient upon final transmission of the analytical data.

Requirements for calibration are documented and include:

- A written description of the calibration process used for major measurement parameters.

- $\quad$ Frequency of calibration.

- Calibration standards to be used, as well as their sources and traceability.

Environmental monitoring and laboratory program documents contain required preventive maintenance of equipment used for collection and measurement of environmental data and identify processes for controlling the analyses of samples collected for environmental data operations activities. 


\section{Waste Isolation Pilot Plant Environmental Monitoring Plan \\ DOE/WIPP-99-2194, Rev. 3}

\subsubsection{Design}

The design of sampling methodologies is documented and approved. The following requirements for sample design are addressed in environmental program documents:

- Description of techniques or guidelines used to select sampling sites

- Charts, flow diagrams, or tables delineating sampling program operations

- Description of containers, procedures, reagents, etc., used for sample collection, preservation, transport, and storage

- Special conditions for the preparation of sampling equipment and containers to avoid sample contamination

- $\quad$ Sample preservation methods and holding times

- $\quad$ Time considerations for shipment of samples to the laboratory

- Sample custody or chain-of-custody requirements

- $\quad$ Forms, notebooks, databases, and processes to be used to document sample history, sampling conditions, and required analyses

- $\quad$ Requirements for verification and validation of calculations and sample results by independent personnel

\subsubsection{Procurement}

The control of procurement documents ensures that procured items and services meet established requirements and specifications. Basic procurement requirements include:

- $\quad$ Applicable design specifications and other order requirements are referenced in documents for procurement of items and services.

- $\quad$ Supplier has a QA program consistent with applicable requirements.

- $\quad$ Procurement actions be performed in accordance with written procedures that describe the actions involved in the preparation, review, approval, control, and changes of procurement documents.

\subsubsection{Inspection and Acceptance Testing}

Inspection and acceptance testing of specified items and processes are conducted using established acceptance and performance criteria. 


\section{Waste Isolation Pilot Plant Environmental Monitoring Plan \\ DOE/WIPP-99-2194, Rev. 3}

Equipment used for inspections and tests are calibrated and maintained in accordance with procedures and statements of work. These documents describe the calibration process, calibration frequency, and calibration standards to be used, as well as their sources and traceability.

\subsubsection{Management Assessment}

Senior management assembles input from the following sources to form the basis of management assessment:

- $\quad$ Line management's self-assessment reports

- $\quad$ Independent assessment reports

- $\quad$ Corrective action reports, including conditions adverse to quality, nonconformance reports, program deficiency reports, audit reports, and requests for corrective action

Following the assessment, the effectiveness of the QA program is documented. Further, areas for quality improvement (for significant nonconformances or high-risk items/activities), preventive or corrective actions, milestones for completion, responsibility assignments, trend analysis, and lessons learned are documented.

\subsubsection{Independent Assessment}

Independent assessments are performed to verify procedure compliance and are also used to prove independent oversight of the self-assessment process performed by line management. Independent assessments focus on improving items and processes by emphasizing line organization's achievement of quality. Results from independent assessments are transmitted to senior management as input for determining the effectiveness of the integrated QA program. In this regard, personnel performing independent assessments act in a management advisory function.

\subsection{REFERENCES}

10 CFR §830.122. "Quality Assurance Criteria." Code of Federal Regulations, Washington, D.C., Office of the Federal Register, National Archives and Records Administration.

29 CFR §1910.1000. "Occupational Safety and Health Standards: Air Contaminants." Code of Federal Regulations, Washington, D.C., Office of the Federal Register, National Archives and Records Administration.

40 CFR Part 61, Subpart H. "National Emissions Standards for Emissions of Radionuclides Other Than Radon From Department of Energy Facilities," Washington, D.C., Office of the Federal Register, National Archives and Records Administration. 


\section{Waste Isolation Pilot Plant Environmental Monitoring Plan DOE/WIPP-99-2194, Rev. 3}

40 CFR Part 194. "Criteria for the Certification and Recertification of the Waste Isolation Pilot Plant's Compliance with the 40 CFR Part 191 Disposal Regulations." Code of Federal Regulations, Washington, D.C., Office of the Federal Register, National Archives and Records Administration.

40 CFR Part 264. "Standards for Owners and Operators of Hazardous Waste Treatment, Storage, and Disposal Facilities." Code of Federal Regulations, Washington, DC, Office of the Federal Register National Archives and Records Administration.

20.4.1 New Mexico Administrative Code. Title 20, New Mexico Administrative Code, Santa Fe, New Mexico.

ANSI, 1989. Quality Assurance Program Requirements for Nuclear Facilities. ANSI/ASME NQA-1, 1989 Edition.

Corley, J. P., D. H. Denham, R. E. Jaguish, D. E. Michels, A. R. Olsen, and D. A. Waite, 1981. A Guide for Environmental Radiological Surveillance at U.S. Department of Energy Installations. DOE/EP-0023, Washington, D.C., U.S. Department of Energy.

DOE, 1980. Final Environmental Impact Statement, Waste Isolation Pilot Plant. DOE/EIS-0026, Vols. 1 and 2, Washington, D.C., U.S. Department of Energy.

DOE, 1989. Operational Environmental Monitoring Plan for the Waste Isolation Pilot Plant. DOE/WIPP 88-025. Carlsbad, New Mexico, Waste Isolation Pilot Plant, U.S. Department of Energy.

DOE, 1991. Environmental Regulatory Guide for Radiological Effluent Monitoring and Environmental Surveillance. DOE/EH-0173T. Washington, D.C.

DOE, 1992a. Statistical Summary of the Radiological Baseline for the WIPP. DOE/WIPP 92-037. Carlsbad, New Mexico, Waste Isolation Pilot Plant, U.S. Department of Energy.

DOE, 1992b. Summary of the Salt Impact Studies at the WIPP, 1984 to 1990. DOE/WIPP 92-038. Carlsbad, New Mexico, Waste Isolation Pilot Plant, U.S. Department of Energy.

DOE, 1992c. A Study of Disturbed Land Reclamation Techniques for the WIPP. DOE/WIPP 92-039. Carlsbad, New Mexico, Waste Isolation Pilot Plant, U.S. Department of Energy.

DOE, 1992d. Background Water Quality Characterization Report for the WIPP. DOE/WIPP 92-013. Carlsbad, New Mexico, Waste Isolation Pilot Plant, U.S. Department of Energy. 


\section{Waste Isolation Pilot Plant Environmental Monitoring Plan DOE/WIPP-99-2194, Rev. 3}

DOE, 1993. Radiation Protection of the Public and the Environment, DOE Order 5400.5, Change 2, Washington, D.C.

DOE, 1994. Information Management Plan. DOE/CAO-94-1001, Revision 1. Carlsbad, New Mexico, Carlsbad Area Office, U.S. Department of Energy.

DOE, 1997. Environmental Measurement Laboratory Procedures Manual. HASL-300, $28^{\text {th }}$ Edition. New York, N.Y., U.S. Department of Energy.

DOE, 1998. Waste Isolation Pilot Plant RCRA Background Groundwater Quality Baseline Report. DOE/WIPP 98-2285. Carlsbad, New Mexico, Waste Isolation Pilot Plant, U.S. Department of Energy.

DOE, 2006a. Waste Isolation Pilot Plant Contact Handled (CH) Waste Documented Safety Analysis, DOEMIPP 95-2065, Revision 10. Carlsbad New Mexico, Waste Isolation Pilot Plant, U.S. Department of Energy.

DOE, 2006b. Waste Isolation Pilot Plant Remote Handled (RH) Waste Documented Safety Analysis, (DOE/WIPP-06-3174), Revision 0. Carlsbad New Mexico, Waste Isolation Pilot Plant, U.S. Department of Energy.

DOE, 2007. Waste Isolation Pilot Plant Annual Site Environmental Report for 2006. DOE/WIPP 07-2225. Carlsbad, New Mexico, Waste Isolation Pilot Plant, U.S. Department of Energy.

DP-831, New Mexico Environment Department Discharge Permit.

EPA, 1994. Contract Laboratory Program Volatile Organics Analysis of Ambient Air in Canisters. Washington, D.C., U.S. Environmental Protection Agency.

EPA, 1999. TO-15, Determination of Volatile Organic Compounds (VOCs) in Ambient Air Collected in Specially Prepared Canisters and Analyzed by Gas Chromatography/Mass Spectrometry. EPA 625/R-96/0106. Center for Environmental Research Information, Office of Research and Development. Cincinnati, Ohio.

EPA, 2000. Meteorological Monitoring Guidance for Regulatory Modeling Applications. EPA-454/R-99-005, Washington, D.C., U.S. Environmental Protection Agency.

EPA, 2002. EPA QA/G-5, Guidance for Quality Assurance Project Plans, EPA/240/R-02/009. December 2002. Washington, D.C., U.S. Environmental Protection Agency.

Mercer, J. W., 1983. Geohydrology of the Proposed Waste Isolation Pilot Plant Site, Los Medanos Area, Southeastern New Mexico. U.S. Geological Survey, Water-Resources Investigations Report 83-4016. 


\section{Waste Isolation Pilot Plant Environmental Monitoring Plan DOE/WIPP-99-2194, Rev. 3}

New Mexico Environment Department, 1999. Hazardous Waste Facility Permit, \#NM4890139088-TSDF.

Powers, D. W., S. J. Lambert, S. E. Shaffer, L. R. Hill, W. D. Weart (editors), 1978. Geological Characterization Report, Waste Isolation Pilot Plant (WIPP) Site, Southeastern New Mexico, Sandia National Laboratories Report SAND 78-1596, Vols. 1 and 2. Albuquerque, New Mexico, Sandia National Laboratories.

WTS, WP 02-1, WIPP, Groundwater Monitoring Program Plan. Carlsbad, New Mexico, Washington TRU Solutions LLC.

WTS, WP 02-EM.01, WIPP Meteorological Quality Assurance Plan. Carlsbad, New Mexico, Washington TRU Solutions LLC.

WTS, WP 02-EM1001, Sewage Lagoon Sampling. Carlsbad, New Mexico, Washington TRU Solutions, LLC.

WTS, WP 02-EM1005, Groundwater Serial Sample Analysis. Carlsbad, New Mexico, Washington TRU Solutions LLC.

WTS, WP 02-EM1006, Final Sample and Serial Sample Collection. Carlsbad, New Mexico, Washington TRU Solutions, LLC.

WTS, WP 02-EM1011, Biotic Sampling. Carlsbad, New Mexico, Washington TRU Solutions LLC.

WTS, WP 02-EM1012, Airborne Particulate Sampling. Carlsbad, New Mexico, Washington TRU Solutions LLC.

WTS, WP 02-EM1014, Groundwater Level Measurement. Carlsbad, New Mexico, Washington TRU Solutions LLC.

WTS, WP 02-EM1017, Surface Water and Sediment Sampling for Radiological Analysis. Carlsbad, New Mexico, Washington TRU Solutions LLC.

WTS, WP 02-EM1019, Vegetation Sampling. Carlsbad, New Mexico, Washington TRU Solutions LLC.

WTS, WP 12-RL.01, Radiochemistry Quality Assurance Plan. Carlsbad, New Mexico, Washington TRU Solutions LLC.

WTS, WP 13-1, Washington TRU Solutions LLC Quality Assurance Program Description. Carlsbad, New Mexico, Washington TRU Solutions LLC.

WTS, WP 15-PR, WIPP Records Management Program. Carlsbad, New Mexico, Washington TRU Solutions LLC. 